University of Nebraska - Lincoln

DigitalCommons@University of Nebraska - Lincoln

Biological Systems Engineering: Papers and

Publications

Biological Systems Engineering

2020

\title{
Influence of Setback Distance on Antibiotics and Antibiotic Resistance Genes in Runoff and Soil Following the Land Application of Swine Manure Slurry
}

\author{
Maria C. Hall \\ University of Nebraska - Lincoln, cissi.hall@hotmail.com \\ Noelle Mware \\ University of Nebraska - Lincoln, nmware@huskers.unl.edu \\ John E. Gilley \\ USDA-ARS, john.gilley@ars.usda.gov \\ Shannon L. Bartelt-Hunt \\ University of Nebraska - Lincoln, sbartelt2@unl.edu \\ Daniel D. Snow \\ University of Nebraska - Lincoln, dsnow1@unl.edu \\ Follow this and additional works at: https://digitalcommons.unl.edu/biosysengfacpub \\ See next page for additional authors \\ Part of the Bioresource and Agricultural Engineering Commons, Environmental Engineering Commons, \\ and the Other Civil and Environmental Engineering Commons
}

Hall, Maria C.; Mware, Noelle; Gilley, John E.; Bartelt-Hunt, Shannon L.; Snow, Daniel D.; Schmidt, Amy M. Schmidt; Eskridge, Kent M.; and Li, Xu, "Influence of Setback Distance on Antibiotics and Antibiotic Resistance Genes in Runoff and Soil Following the Land Application of Swine Manure Slurry" (2020). Biological Systems Engineering: Papers and Publications. 677.

https://digitalcommons.unl.edu/biosysengfacpub/677

This Article is brought to you for free and open access by the Biological Systems Engineering at DigitalCommons@University of Nebraska - Lincoln. It has been accepted for inclusion in Biological Systems Engineering: Papers and Publications by an authorized administrator of DigitalCommons@University of Nebraska Lincoln. 


\section{Authors}

Maria C. Hall, Noelle Mware, John E. Gilley, Shannon L. Bartelt-Hunt, Daniel D. Snow, Amy M. Schmidt Schmidt, Kent M. Eskridge, and Xu Li 


\section{Influence of Setback Distance on Antibiotics and Antibiotic Resistance Genes in Runoff and Soil Following the Land Application of Swine Manure Slurry}

Maria C. Hall, Noelle A. Mware, John E. Gilley, Shannon L. Bartelt-Hunt, Daniel D. Snow, Amy M. Schmidt, Kent M. Eskridge, and $\mathrm{Xu} \mathrm{Li*}$

Cite This: Environ. Sci. Technol. 2020, 54, 4800-4809

Read Online

ABSTRACT: The environmental spread of antibiotics and antibiotic resistance genes (ARGs) from the land application of livestock wastes can be a potential public health threat. The objective of this study was to assess the effects of setback distance, which determines how close manure may be applied in relation to surface water, on the transport of antibiotics and ARGs in runoff and soil following land application of swine manure slurry. Rainfall simulation tests were conducted on field plots covered with wheat residues, each of which contained an upslope manure region where slurry was applied and an adjacent downslope setback region that did not receive slurry. Results show that all three antibiotics (chlortetracycline, lincomycin, and tiamulin) and seven out of the ten genes tested (erm(B), erm (C), intI1, tet $(\mathrm{O}), \operatorname{tet}(\mathrm{Q}), \operatorname{tet}(\mathrm{X})$, and the $16 \mathrm{~S}$ rRNA gene) decreased significantly in runoff with increased setback distance. Only $b{ } a_{\mathrm{TEM}}$, chlortetracycline, and tiamulin decreased significantly in surface soil with increased setback distance, while the

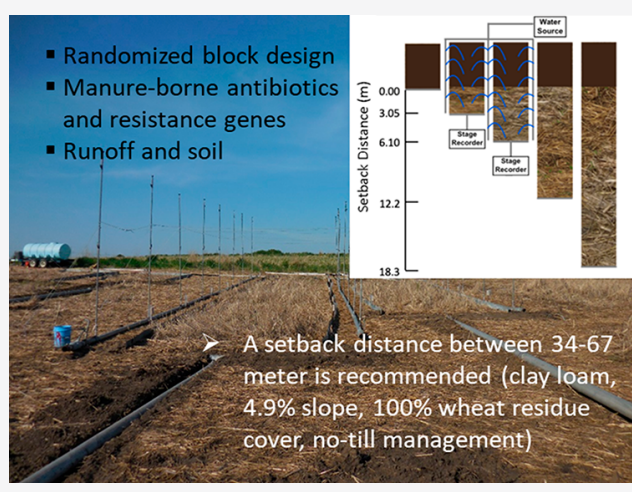
other analytes did not exhibit statistically significant trends. By using linear regression models with field data, we estimate that a setback distance between 34-67 m may allow manure-borne antibiotics and ARGs in runoff to reach background levels under the experimental conditions tested.

\section{INTRODUCTION}

Antibiotic resistance in the environment poses a potential threat to public health. ${ }^{1}$ One source of antibiotics and antibiotic resistance genes (ARGs) in the environment is manure from livestock receiving antibiotics for disease prevention and treatment ${ }^{2}$ in concentrated animal feeding operations (CAFOs). ${ }^{3}$ A range of unmetabolized antibiotics are released in manure together with antibiotic resistant bacteria (ARB) and ARGs. ${ }^{4}$ When swine manure slurry is land applied as a soil amendment to supplement chemical fertilizers in soil nutrient programs, manure borne ARGs are introduced to the environment and can persist in the soil for up to several weeks. ${ }^{6}$ With rainfall or irrigation, manure borne antibiotics and ARGs may contaminate surface water through runoff.

Best management practices (BMPs) are important for minimizing the transport of manure-borne contaminants to surface water. Examples of BMPs are lagoon treatment, soil incorporation of manure during field application, vegetated filter strips, and eliminating high risk areas from manure application such as steeply sloping land and low lying land that tends to flood. 8,9 Another recommendation that is used to prevent water contamination is the use of setback distances. Setback distance refers to the minimum distance between an area where manure is land applied and a water source or residential/commercial area. ${ }^{10}$ The Environmental Protection
Agency (EPA) requires large CAFOs to implement a setback distance for manure application at least $100 \mathrm{ft}(30.5 \mathrm{~m})$ from surface waters and conduits to surface waters, or substitute with a $35 \mathrm{ft}(10.7 \mathrm{~m})$ vegetated buffer. ${ }^{11}$ Several states currently regulate setback distances from manure application to landscape features such as wells, streams, ponds, and property lines. Missouri, for example, has a recommended setback distance of $300 \mathrm{ft}(91.4 \mathrm{~m})$ from wells, $100 \mathrm{ft}(30.5 \mathrm{~m})$ from streams, and $150 \mathrm{ft}(45.7 \mathrm{~m})$ from neighboring houses. ${ }^{12}$ Iowa requires a $200 \mathrm{ft}(61.0 \mathrm{~m})$ setback distance from drinking water wells and an $800 \mathrm{ft}(244 \mathrm{~m})$ setback distance from high quality water sources for unincorporated manure application. The 200 and $800 \mathrm{ft}$ setback distances can be decreased to $50 \mathrm{ft}$ $(15 \mathrm{~m})$ with a buffer strip. ${ }^{13}$ These regulations or recommendations on setback distances are often based on the standards on the concentration and mass of nutrients in precipitation-related discharges set forth by regulatory

Received: August 9, 2019

Revised: $\quad$ March 23, 2020

Accepted: March 24, 2020

Published: March 24, 2020 

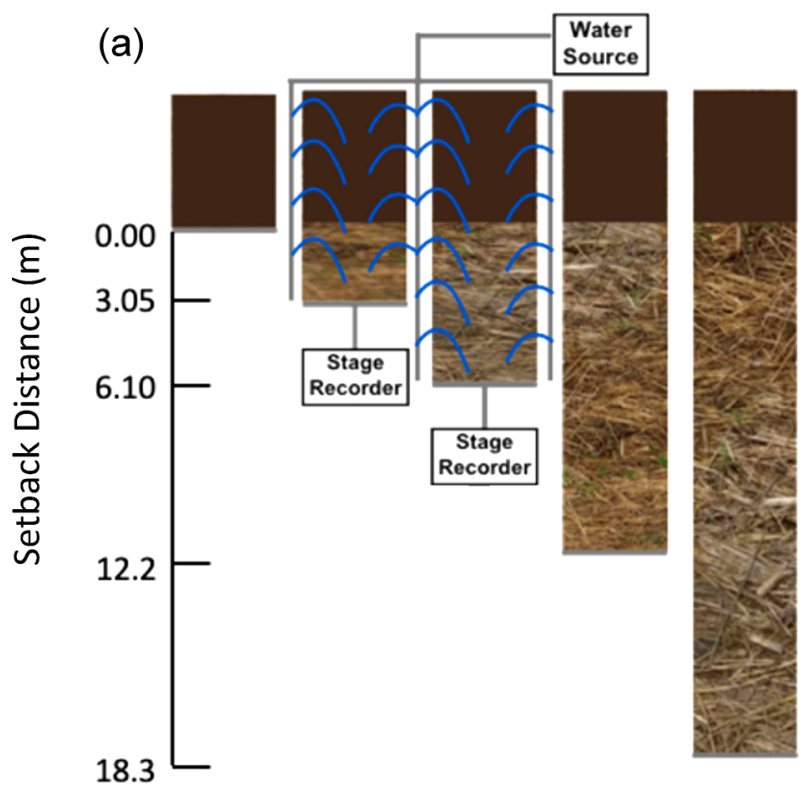

(b)

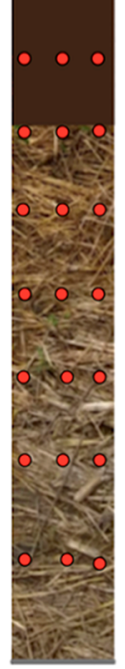

Manure

Region

Setback

Region

Figure 1. (a) Plots with various setback distances. For each setback distance, four replicate plots were randomly assigned. Two plots were run each week. Runoff samples were collected at the end of each plot when the surface runoff reached steady-state flow. (b) The locations of soil cores (red dots) collected in the manure region and at various setback distances in the setback region of the longest plot. Images are not drawn to scale.

agencies. $^{11}$ There are no such standards for antibiotics or ARGs.

The goal of this study is to determine the setback distance needed to minimize the transport of antibiotics and ARGs in agricultural runoff following the land application of swine manure slurry. Specifically, we (1) investigated the effectiveness of varying setback distances on the removal of antibiotics and ARGs in runoff and soil, (2) determined the effect of two back-to-back rainfall events on the concentration of antibiotics and ARGs in runoff, and (3) identified the vertical transport distance for antibiotics and ARGs in soil. Simulated rainfall tests were conducted on replicate plots in the field established using a randomized complete block design. Runoff and soil samples were collected from plots with varying setback distances. The results were analyzed using ANOVA with GLIMMIX to determine the effectiveness of setback distance on contaminant levels in runoff and soil. Outcomes of the study can be used in determining the setback distances needed to protect surface water quality from the antibiotics and ARGs in runoff from manure land application sites.

\section{MATERIALS AND METHODS}

Study Site. The study site was located at the University of Nebraska Rogers Memorial Farm, $18 \mathrm{~km}$ east of Lincoln, NE. The area chosen for this study had uniform crop residue and a slope of $4.9 \%$. The area had previously been used to grow corn, sorghum, soybeans, and winter wheat. No manure had been applied to the study area since 1966. Winter wheat was harvested prior to the field tests, and glyphosate was applied for weed control. The wheat residue was not removed and gave the soil surface $100 \%$ coverage during the study period. The soil type was Aksarben silty clay loam (fine, smectite, mesic Typic Argiudoll), which is a benchmark soil for the corn belt.

Plot Setup. The field tests were conducted over a 10 -week period in summer 2016. Twenty (20) plots were established in the study area using a randomized complete block design. Within each of the four blocks, five setback distances $(0.0,3.0$, $6.1,12.2$, and $18.3 \mathrm{~m}$ ) were randomly assigned to the plots.
The longest plots that we could set up in the field measured $18.3 \mathrm{~m}$ in length. All plots were $3.7 \mathrm{~m}$ wide. At the top of each plot, a $3.7 \mathrm{~m} \times 4.9 \mathrm{~m}$ area was designated as the manure region to receive swine manure slurry. Downslope from the manure region was the setback region, whose length was determined by the assigned setback distance (Figure 1a). At the end of each plot was a metal lip that could collect runoff and direct it through a flume, where flow could be measured by a stage recorder. During natural rainfall events, the plots were covered with plastic sheets.

Simulated rainfall was generated with a portable rainfall simulator sprinkler system ${ }^{14}$ consisting of $3 \mathrm{~m}$ sections of 10 $\mathrm{cm}$ diameter irrigation pipes, on which $2 \mathrm{~cm}$ diameter risers were mounted. Sprinkler heads (Model 78C, Rain Jet Corporation) were located on the top of the risers. The rainfall simulation system was placed so that it covered the entire plot area (i.e., manure region plus setback region). Irrigation water was obtained from an onsite irrigation well. The intensity of the rainfall was approximately $52 \mathrm{~mm} \mathrm{hr}^{-1}$, and it was measured using rain gauges placed along the perimeters of the plots.

Manure Collection and Characterization. Manure slurry was collected from a commercial swine operation facility in southeast Nebraska each week. Manure slurry samples were sent to Wards Laboratory for characterization (Grand Island, $\mathrm{NE}$ ). The mean values and standard deviations for $\mathrm{NO}_{3}{ }^{-} \mathrm{N}$, $\mathrm{NH}_{4}{ }^{+}-\mathrm{N}$, total Kjeldahl $\mathrm{N}$, organic $\mathrm{N}$, total phosphorus (TP), $\mathrm{pH}$, and solids content of the slurry were $0.98 \pm 0.64 \mathrm{mg} \mathrm{kg}^{-1}$, $2.98 \pm 0.33 \mathrm{~g} \mathrm{~kg}^{-1}, 5.52 \pm 0.57 \mathrm{~g} \mathrm{~kg}^{-1}, 2.54 \pm 0.67 \mathrm{~g} \mathrm{~kg}^{-1}, 6.95$ $\pm 0.88 \mathrm{~g} \mathrm{~kg}^{-1}, 7.81 \pm 0.19$, and $5.35 \pm 0.67 \%$, respectively.

Rainfall Simulation Tests. Each week, two plots were used for rainfall simulation tests. In a typical week, rainfall simulations were conducted on the pair of plots on days 1 and 2 under existing antecedent soil moisture. On day 3, the manure slurry was collected and broadcast onto the manure region of the plots by hand at the rate of $3.90 \times 10^{4} \mathrm{~kg}$ liquid slurry $\mathrm{ha}^{-1}$. The rate was based on an annual nitrogen requirements for corn of $151 \mathrm{~kg} \mathrm{~N} \mathrm{ha}^{-1}$ year $^{-1}$ for an expected 
yield of $9.4 \mathrm{Mg} \mathrm{ha}^{-1} .^{15}$ On days 4 and 5, rainfall simulation tests were conducted again on the plots.

During rainfall simulation tests when the runoff flow reached steady state based on hydrographs, grab samples of runoff were collected in one $250 \mathrm{~mL}$ amber glass jar for antibiotics analysis and in two 1-L sterile plastic bottles for nutrient and microbial analyses. Samples were stored on ice and shipped back to the laboratory for further analysis.

For the plots with the longest setback distance, 5 days after the last rainfall simulation, three replicate soil cores were collected from the middle of the manure region as well as at $0.0,3.0,6.1,9.1,12.2$, and $15.2 \mathrm{~m}$ setback distances in the setback region (Figure $1 \mathrm{~b}$ ). The soil cores were $30 \mathrm{~cm}$ long and were later divided into three layers: $0-10,10-20$, and $20-30 \mathrm{~cm}$. Soil segments from the same depth of the triplicate cores were combined, transported on ice to the laboratory, and stored in freezers until further analysis. Plots with the longest setback distance (i.e., $18.3 \mathrm{~m}$ ) were also used to generate controls for runoff (i.e., runoff from the plots prior to manure application) and soil (i.e., soil from the plots prior to manure application and any rainfall simulation).

ARG Analysis. Soil samples were thawed at $4{ }^{\circ} \mathrm{C}$ and homogenized by hand. Frozen runoff and manure slurry samples were thawed overnight at $4{ }^{\circ} \mathrm{C}$. A $50 \mathrm{~mL}$ portion of runoff sample was filtered through sterile $0.22 \mu \mathrm{m}$ filters, and 5 $\mathrm{mL}$ manure slurry sample was centrifuged. DNA was extracted from $0.25 \mathrm{~g}$ soil, filter paper, or centrifuge pellets using the Qiagen DNeasy PowerSoil Kit following the manufacturer protocol with the exception that two 40-s bead beating steps were used to lyse cells. Extracted DNA was purified with OneStep PCR Inhibitor Removal Kit (Zymo Research). Successful removal of PCR inhibitors was confirmed using end point PCR targeting the $16 \mathrm{~S}$ rRNA gene. ${ }^{16}$ Candidate ARGs detected positive in manure samples using end point PCR were selected for further qPCR analyses, which included $b l a_{\text {TEM }}, \operatorname{erm}(\mathrm{B}), \operatorname{erm}(\mathrm{C}), \operatorname{erm}(\mathrm{F}), \operatorname{intI1}, \operatorname{tet}(\mathrm{D}), \operatorname{tet}(\mathrm{O}), \operatorname{tet}(\mathrm{Q})$, and $\operatorname{tet}(\mathrm{X})$. Detailed $\mathrm{qPCR}$ procedure can be found in the Supporting Information file.

Antibiotic Analysis. On the basis of information given from the swine production facility, four antibiotics (chlortetracycline, lincomycin, penicillin $\mathrm{G}$, and tiamulin), one antibiotic degradation product (penicillic acid), and one sweetener (neotame) were included in the quantification. The sweetener was fed to swine as a growth promoter. The procedure for antibiotic analysis using liquid chromatography tandem mass spectrometry was modified from an earlier study analyzing similar samples. ${ }^{7}$ Detailed procedures are reported in the Supporting Information file. Method detection limits, determined by replicate extraction and analysis of low-level $(0.005 \mu \mathrm{g} / \mathrm{L})$ fortified water ranged from $0.0004 \mu \mathrm{g} / \mathrm{L}$ for penicillin $\mathrm{G}$ to $0.0240 \mu \mathrm{g} / \mathrm{L}$ for lincomycin, with recovery between 60 and 125\%. Method detection limits in solid samples were determined from replicates in clean sand spiked at $1.0 \mathrm{ng} / \mathrm{g}$ and ranged between 0.4 and $2.0 \mathrm{ng} / \mathrm{g}$ with recoveries between 46 and 127\%. A synthetic macrolide, oleandomycin, was added to all samples prior to extraction as a surrogate, and recovery averaged $70 \pm 39 \%$ in all field samples. Quality controls analyzed at a frequency of not less than 1 in $20(5 \%)$ of all field samples included laboratory duplicates, laboratory reagent (method) blanks, laboratory fortified blanks, and laboratory fortified matrix samples.

Statistical Analysis. Split plot in time ANOVA using GLIMMIX in SAS (Cary, NC) with setback distance as the whole plot factor and rainfall event as the "time" factor was used to determine the significance of setback distance on the log concentration of ARGs and antibiotics in runoff and soil. For runoff, treatment factors were setback distance and rainfall events after manure application (i.e., rainfall \#1 and rainfall \#2). For soil, treatment factors were setback distance and depth (i.e., $0-10 \mathrm{~cm}, 10-20 \mathrm{~cm}, 20-30 \mathrm{~cm}$ ). For treatment factors identified by ANOVA as having significant impacts (i.e., $p<0.05$ ), least significant difference (LSD) tests were further conducted. For ARGs/antibiotics significantly impacted by setback distances, multiple regression models were tested and linear regressions were chosen to estimate the relationship between log concentrations of ARGs/antibiotics in runoff and setback distances due to high $\mathrm{R}^{2}$ values.

For statistical analyses that involve a large number of values below detection limits, which occurs mostly in soil samples, we used the following methods to treat these values. Only genes that had values higher than the detection limits in more than $50 \%$ of the samples were analyzed by ANOVA. Antibiotic concentrations below the detection limits were left blank in the input files for SAS analyses. Further, because no antibiotics were consistently detected in lower soil depths, only antibiotics in $0-10 \mathrm{~cm}$ soil depth were analyzed using ANOVA with setback distance as the only factor.

\section{RESULTS}

ARGs and Antibiotics in Manure. The $16 \mathrm{~S}$ rRNA gene and nine other genes related to horizontal gene transfer, tetracycline resistance, macrolide resistance, and penicillin resistance were quantified for manure samples using qPCR (Table 1). Eight out of the ten genes were present in all ten manure samples. The tet( $\mathrm{Q})$ gene was not detected in one manure sample, and tet(D) was detected in only one manure sample.

Table 1. Gene and Antibiotic Concentrations in Swine Manure Slurry Samples (Average \pm Standard Error)

\begin{tabular}{|c|c|c|c|}
\hline Analyte & & Concentration & $\begin{array}{c}\text { Number of } \\
\text { Samples Detected } \\
\text { Positive }(n=10)\end{array}$ \\
\hline \multirow{10}{*}{$\begin{array}{l}\text { Gene } \\
\text { (copies/ } \\
\text { mL) }\end{array}$} & $16 \mathrm{~S}$ rRNA & $(6.9 \pm 1.1) \times 10^{5}$ & 10 \\
\hline & $b l a_{\mathrm{TEM}}$ & $(8.1 \pm 4.4) \times 10^{3}$ & 10 \\
\hline & erm(B) & $(8.6 \pm 2.1) \times 10^{4}$ & 10 \\
\hline & $\operatorname{erm}(\mathrm{C})$ & $(8.9 \pm 3.3) \times 10^{4}$ & 10 \\
\hline & $\operatorname{erm}(\mathrm{F})$ & $(9.5 \pm 2.0) \times 10^{4}$ & 10 \\
\hline & intI1 & $(3.3 \pm 1.0) \times 10^{4}$ & 10 \\
\hline & $\operatorname{tet}(\mathrm{D})$ & $1.6 \times 10^{2}$ & 1 \\
\hline & $\operatorname{tet}(\mathrm{O})$ & $(9.6 \pm 2.3) \times 10^{2}$ & 10 \\
\hline & $\operatorname{tet}(\mathrm{Q})$ & $(3.3 \pm 0.8) \times 10^{3}$ & 9 \\
\hline & $\operatorname{tet}(\mathrm{X})$ & $(7.2 \pm 3.3) \times 10^{4}$ & 10 \\
\hline \multirow{3}{*}{$\begin{array}{l}\text { Antibiotic } \\
\text { (mg/kg } \\
\text { ww) }\end{array}$} & Chlortetracycline & $10.39 \pm 1.45$ & 10 \\
\hline & Lincomycin & $0.23 \pm 0.09$ & 10 \\
\hline & Tiamulin & $0.45 \pm 0.08$ & 10 \\
\hline
\end{tabular}

Out of the six feed additives analyzed, penicillin $\mathrm{G}$, penicillic acid, and neotame were not detected in any manure, runoff, or soil samples. In the manure slurry samples, the most abundant antibiotic was chlortetracycline at $10.39 \pm 1.45 \mathrm{mg} \mathrm{kg}^{-1}$ ww. Lincomycin and tiamulin were also detected in all ten manure slurry samples, at levels about 2 orders of magnitude lower than chlortetracycline (Table 1). 
ARGs in Runoff. The effects of setback distance and rainfall events on the gene concentrations in runoff are reported in Table 2. Out of the ten genes analyzed, the concentrations of the 16S rRNA gene, $\operatorname{erm}(\mathrm{B}), \operatorname{erm}(\mathrm{C}), \operatorname{int} I 1, \operatorname{tet}(\mathrm{O}), \operatorname{tet}(\mathrm{Q})$, and tet $(\mathrm{X})$ in runoff were significantly impacted by setback distance $(p<0.05)$. The ARGs $b l a_{\text {TEM }}$ erm $(\mathrm{F})$, and tet(D) were not significantly impacted by setback distance $(p>0.05)$. For the seven genes that were significantly affected by setback distance, LSD tests showed that their concentrations in runoff decreased as setback distance increased (Table 2).

The least-squares means in runoff from rainfall \#1, for the seven genes significantly affected by setback distance, were plotted against the setback distances in Figure $2 a-c$. The linear regression equations, along with the $\mathrm{R}^{2}$ values, are reported in Table 3. On the basis of the values of the slopes, the seven genes appeared to be classified into three groups. The $16 \mathrm{~S}$ rRNA gene and intI1 both decreased with a slope of 0.064 (log copies per $\mathrm{mL}^{-1}$ per meter of setback distance). The gene tet $(\mathrm{X})$ decreased with a slope of 0.072 , while $\operatorname{erm}(\mathrm{B}), \operatorname{erm}(\mathrm{C})$, tet $(\mathrm{O})$, and tet $(\mathrm{Q})$ decreased most rapidly with a slope between 0.080 and 0.084 . After normalizing to the $16 \mathrm{~S}$ rRNA gene, the relative abundance of the remaining six genes are plotted in Figure $S 1$.

Two genes, $\operatorname{erm}(\mathrm{C})$ and tet $(\mathrm{O})$, exhibited a significant decrease in their concentrations in runoff during rainfall \#2 versus runoff during rainfall \#1 $(p<0.05$, Table 2$)$. The concentrations of these two genes in runoff generated from both rainfalls were plotted against setback distances in Figure S2a,b. At the $p<0.10$ level, the concentrations of $\operatorname{erm}(\mathrm{B})$, intI1, and tet( $\mathrm{Q})$ in runoff during rainfall \#2 were also significantly lower than those in runoff during rainfall \#1.

Eight out of the ten genes analyzed were consistently detected in runoff from simulated rainfalls from control plots (Table S5). ANOVA tests showed that manure amendment had a significant effect $(p<0.05)$ on the ARG concentrations in runoff at the longest setback distance tested $(18.3 \mathrm{~m})$ for $\operatorname{erm}(\mathrm{B}), \operatorname{erm}(\mathrm{C}), \operatorname{erm}(\mathrm{F}), \operatorname{intI1}, \operatorname{tet}(\mathrm{O})$, and tet( $\mathrm{Q})$. For all six genes, the concentrations were higher in runoff from amended plots receiving manure. Because erm $(\mathrm{C})$ and tet $(\mathrm{O})$ in runoff from control plots were below detection limits, $p$-values were not established for them in ANOVA (Table S5). Nonetheless, they were significantly affected by manure amendment. No significant effect from manure amendment was observed on the $16 \mathrm{~S}$ rRNA gene, $b l_{\mathrm{TEM}}$, tet(D), or tet $(\mathrm{X})(p>0.05)$.

With the use of the equations in Table 3 , a setback distance of $36-58 \mathrm{~m}$ is estimated to be necessary to lower the ARG levels in runoff down to background levels, which were defined as either ARG levels in runoff from control plots or qPCR detection limits. The longest setback distance tested in this study was $18.3 \mathrm{~m}$. This distance, for the soil type and rainfall conditions presented here, effectively reduced the ARG concentrations by about $1.2-1.5$ logs.

Antibiotics in Runoff. The effects of setback distance and rainfall events on the concentrations of antibiotics in runoff are reported in Table 2. The concentrations of all three antibiotics in runoff decreased significantly with increased setback distance $(p<0.05)$. The log transformed values of antibiotic concentrations in runoff are plotted against setback distance in Figure $2 \mathrm{~d}$. The relationship can be described using linear trendlines, and the linear equations are reported in Table 3. Tiamulin concentration in runoff decreased the most rapidly followed by chlortetracycline and then lincomycin. Using the approach similar to the one used to estimate the safe setback

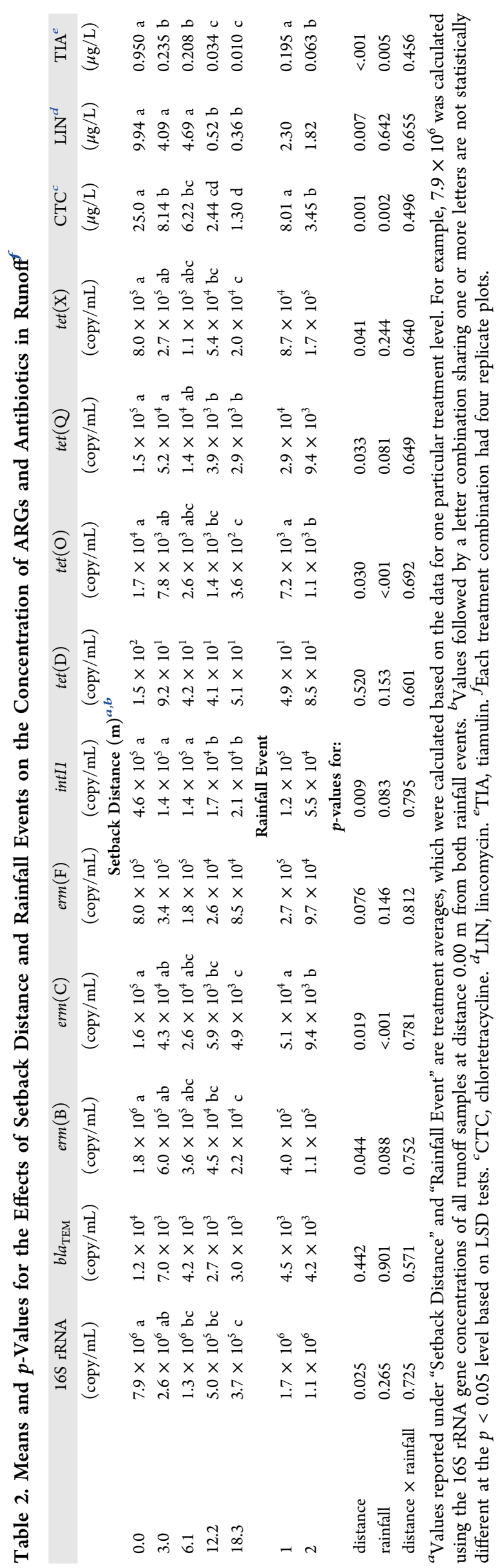

https://dx.doi.org/10.1021/acs.est.9b04834 Environ. Sci. Technol. 2020, 54, 4800-4809 

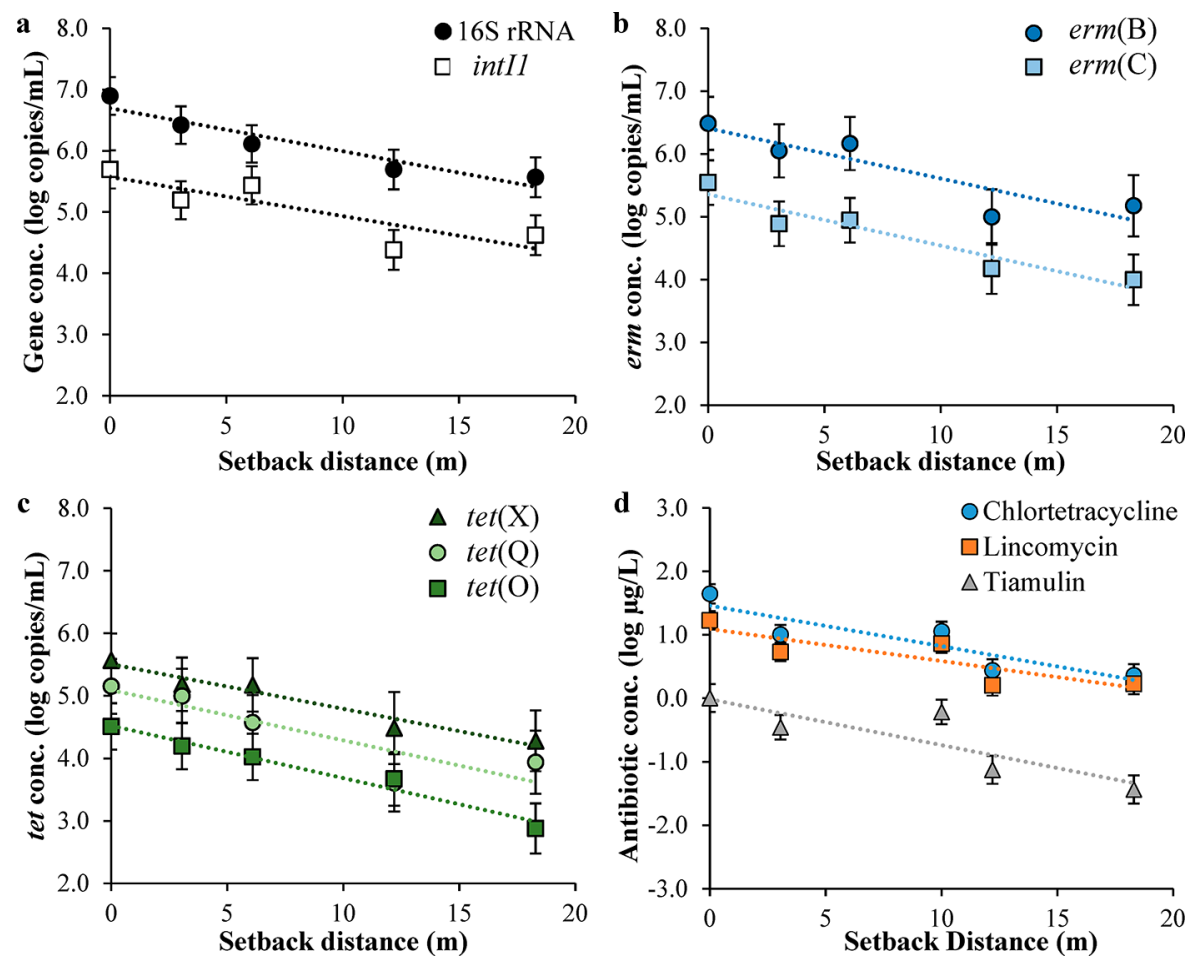

Figure 2. Means of log concentration of (a) the 16S rRNA gene and intI1, (b) erythromycin resistance methylase (erm) genes, (c) tetracycline resistance (tet) genes, and (d) antibiotics in runoff from manure-amended plots after the rainfall \#1. The error bars represent the standard errors based on the ANOVA analysis with GLIMMIX. The trendlines are linear.

Table 3. Linear Regression Equations and $\mathrm{R}^{2}$ for the $\log$ Concentrations of ARGs and Antibiotics in Runoff ${ }^{a}$ As a Function of Setback Distances

\begin{tabular}{|c|c|c|c|c|}
\hline Analytes & & $\begin{array}{c}\text { Linear } \\
\mathrm{Eq}^{b}(\mathrm{ax}+ \\
\mathrm{b})\end{array}$ & $\mathrm{R}^{2}$ & $\begin{array}{l}\text { Setback Distance } \\
\text { Requirement }^{c}(\mathrm{~m})\end{array}$ \\
\hline \multirow{7}{*}{$\begin{array}{l}\text { Gene (log } \\
\text { copies/ } \\
\mathrm{mL})\end{array}$} & $16 \mathrm{~S}$ rRNA & $\begin{array}{l}-0.064 x \\
+6.737\end{array}$ & 0.913 & 43 \\
\hline & erm(B) & $\begin{array}{l}-0.080 \mathrm{x} \\
+6.408\end{array}$ & 0.810 & 57 \\
\hline & $\operatorname{erm}(\mathrm{C})$ & $\begin{array}{l}-0.082 \mathrm{x} \\
+5.356\end{array}$ & 0.909 & 39 \\
\hline & intI1 & $\begin{array}{l}-0.064 \mathrm{x} \\
\quad+5.574\end{array}$ & 0.729 & 58 \\
\hline & $\operatorname{tet}(\mathrm{O})$ & $\begin{array}{l}-0.084 \mathrm{x} \\
\quad+4.522\end{array}$ & 0.970 & 40 \\
\hline & $\operatorname{tet}(\mathrm{Q})$ & $\begin{array}{l}-0.081 \mathrm{x} \\
\quad+5.092\end{array}$ & 0.785 & 39 \\
\hline & $\operatorname{tet}(\mathrm{X})$ & $\begin{array}{l}-0.071 \mathrm{x} \\
+5.506\end{array}$ & 0.953 & 36 \\
\hline \multirow{3}{*}{$\begin{array}{l}\text { Antibiotic } \\
(\log \mu \mathrm{g} / \\
\mathrm{L})\end{array}$} & Chlortetracycline & $\begin{array}{l}-0.066 \mathrm{x} \\
\quad+1.426\end{array}$ & 0.862 & 56 \\
\hline & Lincomycin & $\begin{array}{l}-0.054 \mathrm{x} \\
+1.079\end{array}$ & 0.824 & 67 \\
\hline & Tiamulin & $\begin{array}{l}-0.079 \mathrm{x} \\
-0.016\end{array}$ & 0.905 & 34 \\
\hline
\end{tabular}

${ }^{a}$ On the basis of weighted averages from rainfall \#1. Only compounds with a significant reduction due to length are shown here. ${ }^{b} \mathrm{x}$ is setback distance in meters. ${ }^{c}$ Setback distance needed to lower the analyte concentrations in runoff to the background levels, which were defined by the analyte concentrations in runoff from the control plots or by the detection limit. The distance requirement was calculated using the linear equations in the table. distance for ARGs, it was found that a setback distance of 34$67 \mathrm{~m}$ would be necessary to lower the antibiotic concentrations in runoff to background levels (Table 3).

The concentrations of two antibiotics, chlortetracycline and tiamulin, in runoff during rainfall \#2 were significantly lower than those in runoff during rainfall \#1 $(p<0.05$, Table 2, Figure S2c,d). The concentration of lincomycin in runoff did not significantly differ between the two rainfall events $(p=$ 0.642 ). ANOVA tests showed that manure amendment had significant effects on the concentrations of all three antibiotics in runoff (Table S5).

ARGs in Soil. The effects of setback distance and soil depth on gene concentrations in soil are presented in Table 4. Among the ten genes tested, four genes were consistently detected above their detection limits in soil samples at most of the setback distances tested, the $16 \mathrm{~S}$ rRNA gene, bla $a_{\mathrm{TEM}}$, intI1, and tet(D). Among them, $b l a_{\text {TEM }}$ was significantly affected by the setback distance $(p<0.05)$ and its concentration in soil dropped significantly between setback distances of 0.0 and 6.1 $\mathrm{m}$ (Table 4). The concentrations of $b l a_{\text {TEM }}$ in $0-10 \mathrm{~cm}$ soil were plotted against setback distances in Figure $3 \mathrm{a}$.

The concentrations of all four genes consistently detected in soil were all significantly affected by soil depth (Table 4). With the exception of $b l a_{\mathrm{TEM}}$, the other three genes had higher concentrations in $0-10 \mathrm{~cm}$ soil than in $20-30 \mathrm{~cm}$ soil.

ANOVA tests showed that manure amendment had significant effects on intIl $(p=0.003)$ and no significant effect on the concentrations of the 16S rRNA gene, bla $a_{\mathrm{TEM}}$, and tet(D) in soil (Table S6). Because the other six genes were not detected in the soil from the control plots, $p$-values were not established for them in ANOVA. Nonetheless, they were significantly affected by manure amendment. 


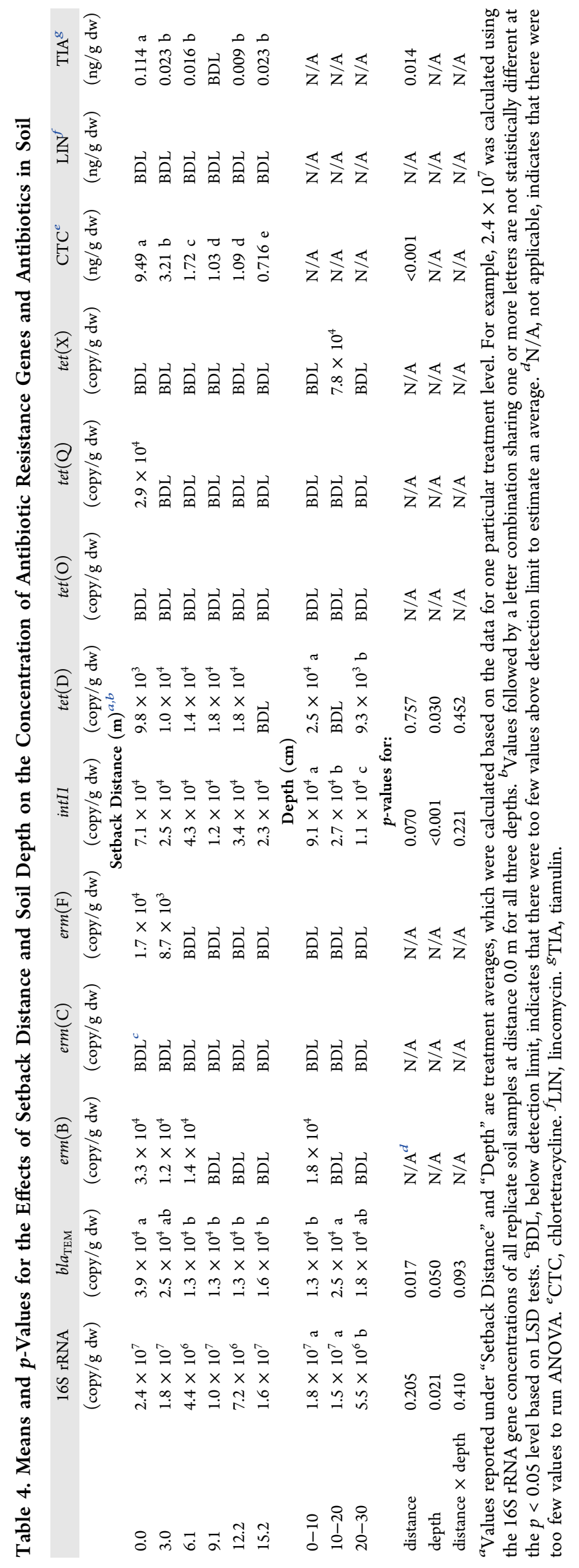



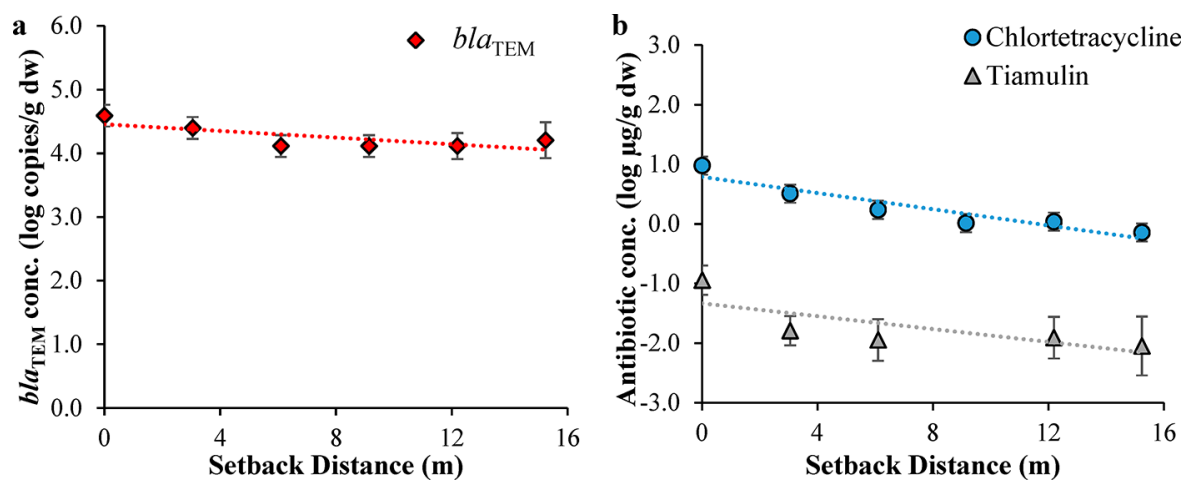

Figure 3. Means of the log concentration of (a) bla $a_{\mathrm{TEM}}$ and (b) antibiotics in $10-20 \mathrm{~cm}$ soil in the setback region. The error bars represent the standard errors based on the ANOVA analysis using GLIMMIX. The trendlines are linear after the data has been log transformed.

Antibiotics in Soil. Because no antibiotics were detected in soil past a depth of $10 \mathrm{~cm}$, setback distance was the only treatment factor subject to ANOVA analysis. Chlortetracycline and tiamulin were detected in the surface soil at almost all setback distances and decreased significantly with increased setback distance $(p<0.05)$ (Table 4 , Figure 3b). Lincomycin was detected in the surface soil of the manure region but not in the surface soil of the setback region.

ANOVA tests showed that manure amendment had significant effects on the concentration of chlortetracycline in soil $(p=0.017$, Table S6). Since lincomycin and tiamulin were not detected in the soil from the control plots, $p$-values were not established for them in ANOVA. Nonetheless, they were significantly affected by manure amendment.

\section{DISCUSSION}

ARGs in Runoff. Information on the transport of ARGs in runoff as a function of setback distance is very limited in the literature. However, studies that investigated the transport of bacteria in runoff can provide useful references for this study. In one study, E. coli cells in runoff, which were originally sprayed on bare soil, decreased by about 0.062 log CFU per $\mathrm{mL}$ per meter of increased setback distance on plots with either 2 or $6 \%$ slope. $^{17}$ The use of free bacteria could potentially overestimate the transport distance for bacteria, which often attach to larger manure particles, in runoff. ${ }^{18,19}$ In another study, E. coli, PRD1 bacteriophage, and Cryptosporidium parvum, which were originally inoculated in bovine fecal pats prior to land application, decreased in runoff by 0.058 to $0.208 \log$ per $\mathrm{mL}$ per meter of increased setback distance with a minimum slope of $18 \%{ }^{20}$ The rates of ARG reduction in runoff reported in this study (Table 3 ) were within the range reported in these other studies.

Several mechanisms could account for the reduction of ARG concentrations in runoff with increased setback distance. The most important mechanism is dilution. As manure particles, which up to $50 \%$ of manure-borne bacteria are attached to, ${ }^{21-23}$ were flushed away from the manure region, additional water was added to the runoff from rainfall over the setback region, diluting ARG concentrations in runoff. Given the experimental conditions used in this study (i.e., the size of the manure region and the setback region), it was estimated that dilution alone could reduce ARG concentration in runoff by 0.036 logs per $\mathrm{mL}$ per meter of increased setback distance.

Another potentially important mechanism is sedimentation. According to a batch study using clay loam soil, approximately $35 \%$ of bacteria tended to attach to particles $>2 \mu \mathrm{m}$ in diameter, particularly those with a dimension of $16-30 \mu \mathrm{m} .{ }^{18}$ Manure particles larger than $40 \mu \mathrm{m}$ can settle within the first five meters of a setback distance. ${ }^{24}$ Microbes that are not attached to larger manure particles are either attached to smaller particles, ${ }^{18}$ which tend to settle slower, or are free as single cells. ${ }^{22}$ Consequently, swine manure slurry containing smaller particles may lead to higher bacterial concentrations in runoff than would solid manure, such as cattle manure. ${ }^{25,26}$

Filtration by the crop residues may also contribute to the reduction of ARGs in runoff. Vegetative filter strips (VFSs) can significantly reduce the concentration of fecal coliforms in runoff. One study found that a $30-\mathrm{m}$ VFS reduced bacterial concentration in runoff by $67-84 \%,{ }^{27}$ while another study reported that a 6.1-m VFS could remove fecal coliforms by $100 \%{ }^{28}$ Similar to a VFS, crop residues in the field can reduce the runoff velocity and increase sedimentation and filtration. ${ }^{29}$ Hence, it is plausible to expect the crop residues, which completely covered the test plots in this study, would contribute to the reduction of ARGs in runoff.

We believe that reporting the absolute abundance of ARGs is more appropriate for this study than relative abundance normalized to the 16S rRNA gene. As shown in Table 3, the slopes of the ARGs are slightly lower (i.e., more negative) than the $16 \mathrm{~S}$ rRNA. Had we normalized these genes to the $16 \mathrm{~S}$ rRNA gene, the relative abundance would decrease at higher slopes (i.e., less negative) than the absolute abundance along setback distance. This would underestimate the effects of setback distance on controlling ARG levels in runoff. Also, in this work, we did not specifically separate genes in intracellular DNA from those in extracellular DNA, because our previous study shows that on average ARGs in extracellular DNA accounted for less than $0.5 \%$ of the total ARGs in swine treatment lagoons, an environment similar to the pits where we collected swine manure slurry for this study. ${ }^{30}$

ARGs in Soil. After manure application and simulated rainfall, the concentration of ARGs in soil generally decreased with increasing soil depth. Most of the genes were not detected beneath the top $10 \mathrm{~cm}$ soil layer or past the first $6 \mathrm{~m}$ of setback distance (Table 4). The exception were the genes that were consistently detected in original soil (i.e., the 16S rRNA gene, $b l a_{\mathrm{TEM}}$, intI1, and tet(D)). These results are consistent with another study where no increase in ARG concentrations was observed at 5-20 cm soil depth following repeated rainfall events on soil receiving dairy manure through surface application. ${ }^{6}$

Variability of Genes. Out of the genes that decreased significantly in runoff with increasing setback distance, the $16 \mathrm{~S}$ 
rRNA gene and intI1 had the least steep slopes (Table 3). This was likely due to the fact that these two genes were naturally occurring in soil (Table S6). Hence, in addition to the soil in the manure region (i.e., manure-amended soil), the soil in the setback region also contributed these genes to runoff. ${ }^{31}$

Setback distance had no significant impacts on the concentrations of $b a_{\mathrm{TEM}}(\mathrm{p}=0.442$, Table 2$)$ or tet $(\mathrm{D})(\mathrm{p}$ $=0.520)$ in runoff. The gene $b l a_{\mathrm{TEM}}$ was the only gene that decreased significantly in soil as a function of setback distance, primarily due to the drop in the first $6.1 \mathrm{~m}$ within the setback region (Table 4). The results from runoff and soil together suggest that some of the bacterial host(s) of the $b l a_{\text {TEM }}$ gene quickly settled to soil while other host(s) of the gene largely remained in runoff. The gene tet(D) was the only gene that was not consistently detected in swine manure slurry (Table $1)$. In the meantime, the average concentration of tet(D) in the original soil was $1.6 \times 10^{4}$ copies per g soil dry weight $(\mathrm{dw})$. Hence, the manure likely was not the main source of this ARG in the runoff.

Antibiotics in Manure. Chlortetracycline, lincomycin, and tiamulin were detected in manure slurry, while penicillin was not detected. This was not surprising since $\beta$-lactam antibiotics, including penicillin, have been found to have short half-lives in manure $(5 \text { days })^{32}$ during manure storage. Tetracyclines have half-lives that range between 82 and 150 days. ${ }^{33,34}$ A study examining tiamulin degradation during manure storage found no degradation of tiamulin over the 180day experiment and suggested that the use of this antibiotic should be avoided due to its environmental persistence. ${ }^{5}$ Swine treatment lagoons sampled in Iowa and Ohio exhibited similar trends to what was found in this study. Tetracyclines and macrolides were detected in the $10-500 \mu \mathrm{g} \mathrm{L}^{-1}$ range, while penicillin was detected below or close to the detection limit. ${ }^{35}$

Antibiotics in Runoff and Soil. Chlortetracycline, lincomycin, and tiamulin had distinctive physiochemical properties. Tiamulin has very low solubility in water ${ }^{36}$ and will therefore likely have a high adsorption coefficient. Chlortetracycline has a higher adsorption coefficient than lincomycin $\left(500-1800 \mathrm{~L} \mathrm{~kg}^{-1}\right.$ vs $\left.20-200 \mathrm{~L} \mathrm{~kg}^{-1}\right){ }^{37,38}$ Difference in physiochemical properties can explain the different behaviors of the antibiotics in runoff and soil.

The setback distances required for antibiotics in runoff to drop to the background levels are longer than those required for ARGs (Table 3), because mechanisms like sedimentation and filtration, which apply to both free and attached microbes, are less relevant to the soluble fraction of the antibiotics. Dilution still plays an important role: dilution itself can cause a reduction in concentration at $0.036 \log$ per $\mathrm{mL}$ per meter of setback distance. Adsorption also played a potentially important role for the transport of the soluble portion of antibiotics in runoff. The adsorption coefficient of lincomycin was smaller than the other two antibiotics; consequently, lincomycin had a lower reduction rate in runoff with setback distance (Table 3). However, it is recognized that the estimated setback distances needed to achieve background levels are considerably beyond the experimental setback distances in the experiment and may not be estimated very precisely.

Parallel to this study that focused on ARGs and antibiotics, a companion study was conducted using the same field setup and was focused on the effects of setback distance on nutrients (i.e., dissolved phosphorus, ammonia, total nitrogen, etc.). ${ }^{15}$ Compared to the slopes for antibiotics in Table 3, those for the nutrients in runoff had a wider range of reduction rates with setback distance (i.e., 0.001 to 0.086 logs per meter of increased setback distance). Compared to antibiotics, nutrients generally had lower reduction rates with setback distance, likely because nutrients occurred more extensively in the field than antibiotics (i.e., contributing from both manure and setback regions).

The hydrophobicity of chlortetracycline and tiamulin leads to the occurrence of these compounds in the surface soil of the setback region (Figure $3 \mathrm{~b}$ ), which presumably resulted from the transport of manure particulates to which these antibiotics were adsorbed. The low sorption coefficient explains why lincomycin was not detected in surface soil (Table 4). The half-lives for chlortetracycline, lincomycin, and tiamulin in soil are $24,{ }^{39} 18,{ }^{40}$ and 16 days, $^{41}$ respectively. Given the time frame of our field testing, degradation would not significantly affect the antibiotic concentrations in soil in this study.

Soil texture can affect the vertical transport of antibiotics following manure application. In this study, where the soil in the field was silty clay loam, no antibiotics were detected below a $10 \mathrm{~cm}$ depth at any setback distance following manure application. Another study also reported no or low levels of tetracycline and oxytetracycline in loamy soil deeper than $5 \mathrm{~cm}$ following irrigation on soil amended with cattle manure. ${ }^{42}$ In contrast, chlortetracycline can occur in relatively high concentrations in sandy soil ( $91.6 \%$ sand) as deep as $30 \mathrm{~cm}$ following liquid swine manure application. ${ }^{43}$

The setback distances determined in this study was based on our experimental conditions: cropland management (no-til), location (southeast Nebraska), slope (4.9\%), soil type (silty clay loam), crop residue coverage (100\%), rainfall $(52 \mathrm{~mm}$ $\mathrm{hr}^{-1}, 1$ and 2 days after manure application), etc. To make more general recommendations on setback distances, additional field tests are needed on plots with different soil types, slopes, cropping, and management conditions. Finally, we would like to acknowledge that the setback distances reported in Table 3 were obtained from extrapolation of linear regression models, a potential limitation of the study.

\section{ASSOCIATED CONTENT}

\section{Supporting Information}

The Supporting Information is available free of charge at https://pubs.acs.org/doi/10.1021/acs.est.9b04834.

Antibiotic analytical methods; PCR and qPCR information, antibiotic and ARG concentrations in two rainfall events; antibiotic and ARG concentrations between control and treatment plots (PDF)

\section{AUTHOR INFORMATION}

\section{Corresponding Author}

Xu Li - Department of Civil and Environmental Engineering, University of Nebraska-Lincoln, Lincoln, Nebraska 68588, United States; 이이이.org/0000-0002-1006-3027; Email: xuli@unl.edu

\section{Authors}

Maria C. Hall - Department of Civil and Environmental Engineering, University of Nebraska-Lincoln, Lincoln, Nebraska 68588, United States

Noelle A. Mware - Department of Civil and Environmental Engineering, University of Nebraska-Lincoln, Lincoln, Nebraska 68588, United States 
John E. Gilley - USDA-ARS, Lincoln, Nebraska 68583, United States

Shannon L. Bartelt-Hunt - Department of Civil and Environmental Engineering, University of Nebraska-Lincoln, Lincoln, Nebraska 68588, United States; (1) orcid.org/00000002-2354-7573

Daniel D. Snow - School of Natural Resources, Water Sciences Laboratory, University of Nebraska-Lincoln, Lincoln, Nebraska 68583, United States

Amy M. Schmidt - Department of Biological Systems Engineering, University of Nebraska-Lincoln, Lincoln, Nebraska 68583, United States

Kent M. Eskridge - Department of Statistics, University of Nebraska-Lincoln, Lincoln, Nebraska 68583, United States

Complete contact information is available at:

https://pubs.acs.org/10.1021/acs.est.9b04834

\section{Notes}

The authors declare no competing financial interest.

\section{ACKNOWLEDGMENTS}

The study was funded by the National Pork Board (\#16-072) and National Science Foundation (CBET-1351676). M.C.H. and N.A.M. were partially supported by the Robert B. Daugherty Water for Food Global Institute at the University of Nebraska and USDA (\#2017-68003-26497), respectively.

\section{REFERENCES}

(1) Pruden, A.; Alcalde, R. E.; Alvarez, P. J. J.; Ashbolt, N.; Bischel, H.; Capiro, N. L.; Crossette, E.; Frigon, D.; Grimes, K.; Haas, C. N.; Ikuma, K.; Kappell, A.; LaPara, T.; Kimbell, L.; Li, M. Y.; Li, X.; McNamara, P.; Seo, Y.; Sobsey, M. D.; Sozzi, E.; Navab-Daneshmand, T.; Raskin, L.; Riquelme, M. V.; Vikesland, P.; Wigginton, K.; Zhou, Z. An environmental science and engineering framework for combating antimicrobial resistance. Environ. Eng. Sci. 2018, 35, $1005-1011$.

(2) Berendonk, T. U.; Manaia, C. M.; Merlin, C.; Fatta-Kassinos, D.; Cytryn, E.; Walsh, F.; Burgmann, H.; Sorum, H.; Norstrom, M.; Pons, M. N.; Kreuzinger, N.; Huovinen, P.; Stefani, S.; Schwartz, T.; Kisand, V.; Baquero, F.; Martinez, J. L. Tackling antibiotic resistance: the environmental framework. Nat. Rev. Microbiol. 2015, 13, 310.

(3) EPA. Regulatory Definitions of Large CAFOs, Medium CAFO, and Small CAFOs.

(4) Cheng, W.; Chen, H.; Su, C.; Yan, S. Abundance and persistence of antibiotic resistance genes in livestock farms: a comprehensive investigation in eastern China. Environ. Int. 2013, 61, 1-7.

(5) Schlüsener, M. P.; Von Arb, M. A.; Bester, K. Elimination of macrolides, tiamulin, and salinomycin during manure storage. Arch. Environ. Contam. Toxicol. 2006, 51, 21-28.

(6) Fahrenfeld, N.; Knowlton, K.; Krometis, L. A.; Hession, W. C.; Xia, K.; Lipscomb, E.; Libuit, K.; Green, B. L.; Pruden, A. Effect of manure application on abundance of antibiotic resistance genes and their attenuation rates in soil: field-scale mass balance approach. Environ. Sci. Technol. 2014, 48, 2643-2650.

(7) Joy, S. R.; Bartelt-Hunt, S. L.; Snow, D. D.; Gilley, J. E.; Woodbury, B. L.; Parker, D. B.; Marx, D. B.; Li, X. Fate and transport of antimicrobials and antimicrobial resistance genes in soil and runoff following land application of swine manure slurry. Environ. Sci. Technol. 2013, 47, 12081-12088.

(8) Kaini, P.; Artita, K.; Nicklow, J. W. Optimizing structural best management practices using SWAT and genetic algorithm to improve water quality goals. Water Resour. Manag. 2012, 26, 1827-1845.

(9) Oun, A.; Kumar, A.; Harrigan, T.; Angelakis, A.; Xagoraraki, I. Effects of biosolids and manure application on microbial water quality in rural areas in the US. Water 2014, 6, 3701-3723.
(10) EPA. Managing Manure Nutrients at Concentrated Animal Feeding Operations. (2004).

(11) U.S Environmental Protection Agency. NPDES permit writer's manual for concentrated animal feeding operations. In Water. (2012).

(12) Cromley, S.; Lory, J. Setback Distances for Land Application of Manure. Available at: https://extension2.missouri.edu/g9219.

(13) Iowa Department of Natural Resources. Separation Distances for Land Application of Manure from Open Feedlots \& Confinement Feeding Operations, including SAFOs. (2008).

(14) Schulz, E. F.; Yevjevich, V. M. Experimental investigation of small watershed floods. Complet. Rep. Ser. (Colorado State Univ. Nat. Resour. Center); no. 18 (1970).

(15) Gilley, J. E.; Bartelt-Hunt, S. L.; Eskridge, K. M.; Li, X.; Schmidt, A. M.; Snow, D. D. Setback distance requirements for removal of swine slurry constituents in runoff. Trans. ASABE 2017, $60,1885-1894$.

(16) Suzuki, M. T.; Giovannoni, S. J. Bias caused by template annealing in the amplification of mixtures of 16S rRNA genes by PCR. Appl. Environ. Microbiol. 1996, 62, 625-630.

(17) Abu-Ashour, J.; Lee, H. Transport of bacteria on sloping soil surfaces by runoff. Environ. Toxicol. 2000, 15, 149-153.

(18) Oliver, D. M.; Clegg, C. D.; Heathwaite, A. L.; Haygarth, P. M. Preferential attachment of Escherichia coli to different particle size fractions of an agricultural grassland soil. Water, Air, Soil Pollut. 2007, 185, 369-375.

(19) Muirhead, R. W.; Collins, R. P.; Bremer, P. J. Interaction of Escherichia coli and soil particles in runoff. Appl. Environ. Microbiol. 2006, 72, 3406-3411.

(20) Ferguson, C. M.; Davies, C. M.; Kaucner, C.; Krogh, M.; Rodehutskors, J.; Deere, D. A.; Ashbolt, N. J. Field scale quantification of microbial transport from bovine faeces under simulated rainfall events. J. Water Health 2007, 5, 83-95.

(21) Soupir, M. L.; Mostaghimi, S.; Dillaha, T. Attachment of Escherichia coli and Enterococci to particles in runoff. J. Environ. Qual. 2010, 39, 1019-1027.

(22) Muirhead, R. W.; Collins, R. P.; Bremer, P. J. Erosion and subsequent transport state of Escherichia coli from cowpats. Appl. Environ. Microbiol. 2005, 71, 2875-2879.

(23) Guber, A. K.; Pachepsky, Y. A.; Shelton, D. R.; Yu, O. Effect of bovine manure on fecal coliform attachment to soil and soil particles of different sizes. Appl. Environ. Microbiol. 2007, 73, 3363-3370.

(24) Gharabaghi, B.; Rudra, R. P.; Goel, P. K. Effectiveness of vegetative filter strips in removal of sediments from overland flow. Water Qual. Res. J. Can. 2006, 41, 275-282.

(25) Thurston-Enriquez, J. A.; Gilley, J. E.; Eghball, B. Microbial quality of runoff following land application of cattle manure and swine slurry. J. Water Health 2005, 3, 157-171.

(26) Blaustein, R. A.; Pachepsky, Y. A.; Hill, R. L.; Shelton, D. R. Solid manure as a source of fecal indicator microorganisms: release under simulated rainfall. Environ. Sci. Technol. 2015, 49, 7860-7869.

(27) Fajardo, J. J.; Bauder, J. W.; Cash, S. D. Managing nitrate and bacteria in runoff from livestock confinement areas with vegetative filter strips. J. Soil Water Conserv. 2001, 56, 185-191.

(28) Lim, T. T.; Edwards, D. R.; Workman, S. R.; Larson, B. T.; Dunn, L. Vegetated filter strip removal of cattle manure constituents in runoff. Trans. ASAE 1998, 41, 1375.

(29) Steiner, J. L. Crop residue effects on water conservation. Manag. Agric. residues 76, (1994).

(30) Zhang, Y.; Snow, D. D.; Parker, D.; Zhou, Z.; Li, X. Intracellular and extracellular antimicrobial resistance genes in the sludge of livestock waste management structures. Environ. Sci. Technol. 2013, 47, 10206-10213.

(31) Tyrrel, S. F.; Quinton, J. N. Overland flow transport of pathogens from agricultural land receiving faecal wastes. J. Appl. Microbiol. 2003, 94, 87-93.

(32) Boxall, A. B. A., Fogg, L. A.; Blackwell, P. A.; Kay, P.; Pemberton, E. J.; Croxford, A. Veterinary medicines in the environment. in Reviews of environmental contamination and toxicology 1-91 (Springer, 2004). 
(33) Stone, J. J.; Clay, S. A.; Zhu, Z. W.; Wong, K. L.; Porath, L. R.; Spellman, G. M. Effect of antimicrobial compounds tylosin and chlortetracycline during batch anaerobic swine manure digestion. Water Res. 2009, 43, 4740-4750.

(34) Winckler, C.; Grafe, A. Use of veterinary drugs in intensive animal production. J. Soils Sediments 2001, 1, 66.

(35) Campagnolo, E. R.; Johnson, K. R.; Karpati, A.; Rubin, C. S.; Kolpin, D. W.; Meyer, M. T.; Esteban, J. E.; Currier, R. W.; Smith, K.; Thu, K. M.; McGeehin, M. Antimicrobial residues in animal waste and water resources proximal to large-scale swine and poultry feeding operations. Sci. Total Environ. 2002, 299, 89-95.

(36) Compound Summary for CID 656958. PubChem Available at: https://pubchem.ncbi.nlm.nih.gov/compound/Tiamulin. (Accessed: 11th April 2018)

(37) Teixidó, M.; Granados, M.; Prat, M. D.; Beltrán, J. L. Sorption of tetracyclines onto natural soils: data analysis and prediction. Environ. Sci. Pollut. Res. 2012, 19, 3087-3095.

(38) Wang, C.; Teppen, B. J.; Boyd, S. A.; Li, H. Sorption of lincomycin at low concentrations from water by soils. Soil Sci. Soc. Am. J. 2012, 76, 1222-1228.

(39) Carlson, J. C.; Mabury, S. A. Dissipation kinetics and mobility of chlortetracycline, tylosin, and monensin in an agricultural soil in Northumberland County, Ontario, Canada. Environ. Toxicol. Chem. 2006, 25, 1-10.

(40) Kuchta, S. L.; Cessna, A. J.; Elliott, J. A.; Peru, K. M.; Headley, J. V. Transport of lincomycin to surface and ground water from manure-amended cropland. J. Environ. Qual. 2009, 38, 1719-1727.

(41) Schlüsener, M. P.; Bester, K. Persistence of antibiotics such as macrolides, tiamulin and salinomycin in soil. Environ. Pollut. 2006, 143, 565-571.

(42) Aga, D. S.; O’Connor, S.; Ensley, S.; Payero, J. O.; Snow, D.; Tarkalson, D. Determination of the persistence of tetracycline antibiotics and their degradates in manure-amended soil using enzyme-linked immunosorbent assay and liquid chromatographymass spectrometry. J. Agric. Food Chem. 2005, 53, 7165-7171.

(43) Hamscher, G.; Sczesny, S.; Höper, H.; Nau, H. Determination of persistent tetracycline residues in soil fertilized with liquid manure by high-performance liquid chromatography with electrospray ionization tandem mass spectrometry. Anal. Chem. 2002, 74, 15091518. 


\title{
Supplementary Information
}

\section{Influence of Setback Distance on Antibiotics and Antibiotic Resistance Genes} in Runoff and Soil Following the Land Application of Swine Manure Slurry

Maria C. Hall,${ }^{\dagger}$ Noelle A. Mware,${ }^{\dagger}$ John E. Gilley, ${ }^{\S}$ Shannon L. Bartelt-Hunt,${ }^{\dagger}$ Daniel D. Snow,,

24 Lincoln, NE 68588-0531

25

\author{
Amy M. Schmidt,,$"$ Kent M. Eskridge, ${ }^{\perp}$ and $\mathrm{Xu} \mathrm{Li}^{*}{ }^{* \dagger}$
}

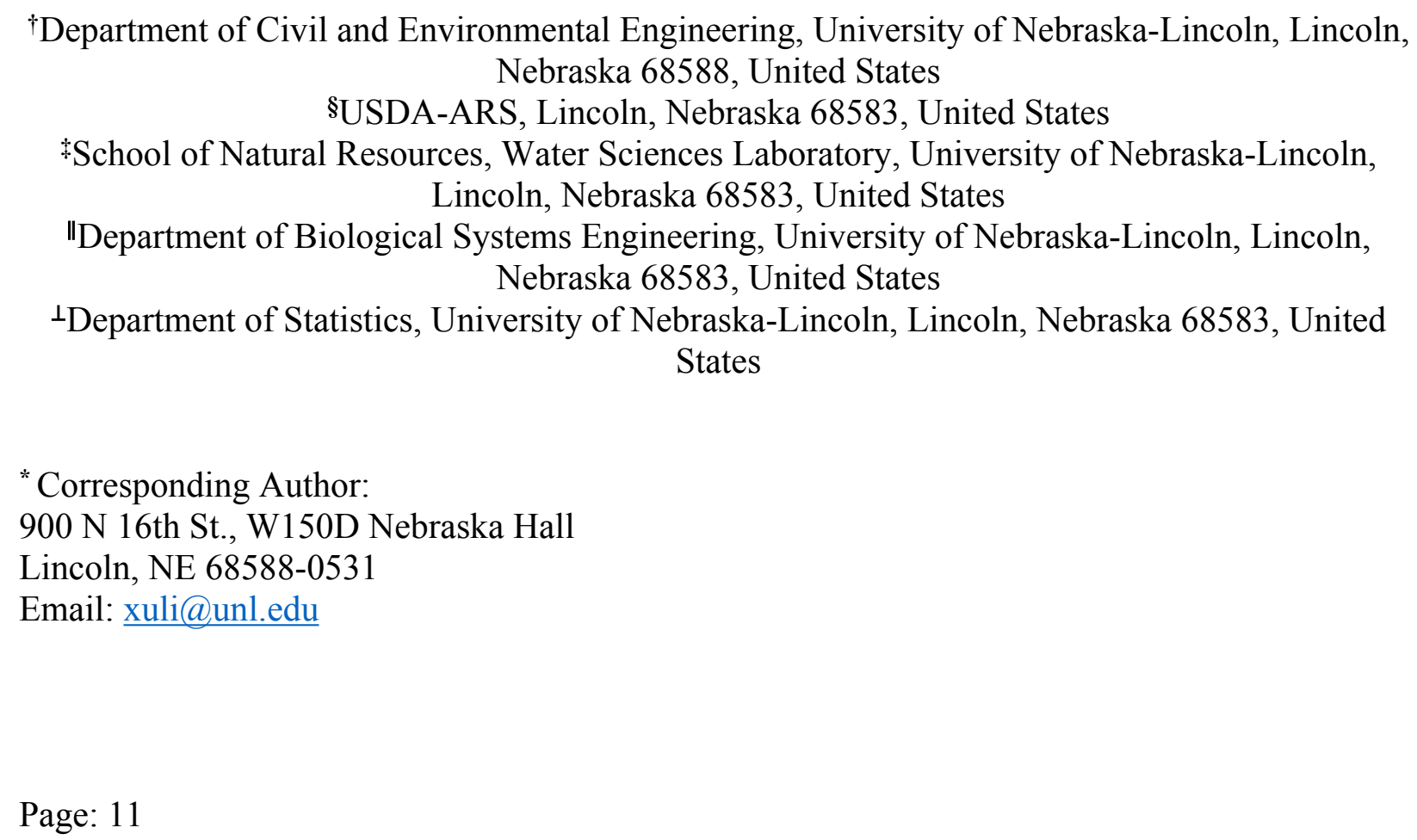

\section{${ }^{*}$ Corresponding Author:}

900 N 16th St., W150D Nebraska Hall

Page: 11

Email: xuli@unl.edu 


\section{MATERIALS AND METHODS}

ARG Analysis. Synthesized gBlocks gene fragments (Integrated DNA Technologies) were used as qPCR standards. The qPCR reactions were performed on an Eppendorf Mastercycler ep realplex 2 thermocycler (Hamburg, Germany) using KiCqStart ${ }^{\circledR}$ SYBR ${ }^{\circledR}$ Green $q$ PCR ReadyMix ${ }^{\mathrm{TM}}$ and KiCqStart ${ }^{\circledR}$ Probe qPCR ReadyMix ${ }^{\mathrm{TM}}$ (Sigma-Aldrich, St. Louis, MO). Assay setup and cycling conditions were adopted from previously reported studies (Tables S1 and S2). Linear ranges and reaction efficiencies are reported in Table S3. Samples were considered below detection limit (BDL), if the results from at least two of the four replicate plots were below the detection limit and the results from the remaining plots were close to the detection limit.

Antibiotic Analyses. Swine slurry and soil were both processed as solid samples during antibiotic extraction. Prior to extraction, swine slurry was mixed with $0.5 \mathrm{~g}$ EDTA and clean sand in a 1:25 ratio by weight. Homogenized soil $(10 \mathrm{~g})$ and swine slurry/sand samples $(5.2 \mathrm{~g})$ were spiked with $100 \mathrm{ng}$ surrogate oleandomycin and mixed with an aqueous buffer (14 mL of $100 \mathrm{mM}$ ammonium citrate plus $4.0 \mathrm{~g} / \mathrm{L}$ ammonia acetate adjusted with ammonium hydroxide to $\mathrm{pH}$ 6) along with $6 \mathrm{~mL}$ of acetonitrile. The mixtures were thoroughly shaken on a Burrell wristaction shaker for $30 \mathrm{~min}$ and centrifuged for $10 \mathrm{~min}$. The solids were extracted a second time using $4 \mathrm{~mL}$ aqueous buffer and and $16 \mathrm{~mL}$ acetonitrile. The supernatants from the two extraction steps were combined and then concentrated on a Labconco RapidVap $\mathrm{N}_{2}$ sample concentrator (Labconco Corporation, Kansas City, MO) at $30^{\circ} \mathrm{C}$ until the volume was reduced by approximately half. Purified reagent water was then added to bring the final volume to $100 \mathrm{~mL}$ prior to solid phase extraction.

Water samples were measured into $100 \mathrm{~mL}$ aliquots, spiked with oleandomycin surrogate and vacuum filtered through pre-combusted $0.5 \mu \mathrm{m}$ Gellman A/E binderless glass fiber filters in tandem with $200 \mathrm{mg}$ Oasis HLB (Waters Corporation, Milford, MA) solid phase extraction (SPE) cartridges preconditioned with $5 \mathrm{~mL}$ acetonitrile followed by $5 \mathrm{~mL}$ high purity (ASTM Type I) reagent water. Aqueous soil and slurry extracts were extracted using the same cartridges. The SPE cartridges were eluted into borosilicate test tubes using $6 \mathrm{~mL}$ mixture of $1 \% 100 \mathrm{mM}$ ammonium acetate $(\mathrm{pH}=4.0)$ plus $99 \%$ acetonitrile. The eluent was evaporated to dryness and concentrated extracts were reconstituted with $200 \mu \mathrm{L}$ of mobile phase containing $100 \mathrm{ng}$ doxycycline, penicillin $\mathrm{V}$, and roxithromycin as internal standards. The $200 \mu \mathrm{L}$ eluent samples were combined with $250 \mu \mathrm{L}$ of mobile phase and then analyzed on an Agilent 1100 high pressure liquid chromatograph (HPLC) coupled with an Agilent 6410 triple quadrupole mass spectrophotometer (Agilent Technologies, Palo Alto, CA) using positive electrospray ionization.

Separation was performed on a $250 \mathrm{~mm} \times 2.1 \mathrm{~mm}$ ID, $5 \mu \mathrm{m}$ particle size HyPURITYTM $\mathrm{C} 18$ column (ThermoFisher, St. Louis, MO) at a temperature of $50^{\circ} \mathrm{C}$ and a gradient flow rate of $0.20 \mathrm{~mL} / \mathrm{min}$. Mobile phase solvents were: A) $1 \mathrm{mM}$ ammonium citrate $(\mathrm{pH}=4)$ in $97 \%$ methanol / 3\% water, and B) $1 \mathrm{mM}$ ammonium citrate $(\mathrm{pH}=4)$ in water. Gradient details were: initial conditions at $0 \%$ A for $1.0 \mathrm{~min}$, linear gradient to reach $75 \% \mathrm{~A}$ at $4 \mathrm{~min}$ and $100 \% \mathrm{~A}$ at $12 \mathrm{~min}$, and $100 \%$ A until $22 \mathrm{~min}$. The column was flushed with $2 \%$ formic acid in methanol for $3 \mathrm{~min}$ and then back to initial conditions $(0 \% \mathrm{~A})$ for $7 \mathrm{~min}$. Total run time is 32 minutes. Multi-reaction monitoring, using a pseudo-molecular ion $[\mathrm{M}+\mathrm{H}]+$ selected as the parent ion for fragmentation and corresponding fragment ion(s), were used for identification and quantitation. Ionization and collision energies are optimized based on procedures described by the instrument manufacturer. Desolvation gas was nitrogen $\left(\mathrm{N}_{2}\right)$ at $12 \mathrm{~L} / \mathrm{min}$, sheathe gas temperature was $350^{\circ} \mathrm{C}$, nebulizer held at $40 \mathrm{psi}$, capillary voltage was $4 \mathrm{kV}$ and cell accelerator voltage at $7 \mathrm{kV}$. Fragmentor and collision energies used for each standard and analyte are given in Table S4. 
81 Table S1. Primers and probes used in qPCR assays

\begin{tabular}{|c|c|c|c|c|c|}
\hline Target gene & Primer & Sequence (5'-3') & $\begin{array}{l}\text { Target } \\
\text { size } \\
\text { (bp) } \\
\end{array}$ & $\begin{array}{c}\text { Annealing } \\
\text { temperature } \\
\left({ }^{\circ} \mathrm{C}\right)\end{array}$ & Reference \\
\hline \multirow[t]{2}{*}{ 16s rRNA } & BACT1369F & CGG TGA ATA CGT TCY CGG & \multirow{2}{*}{142} & \multirow{2}{*}{56} & \multirow{2}{*}{1} \\
\hline & PROK1492R & GGW TAC CTT GTT ACG ACT T & & & \\
\hline \multirow[t]{3}{*}{$b l a \mathrm{TEM}$} & $b l a_{\mathrm{TEM}}-\mathrm{FW}$ & CAC TAT TCT CAG AAT GAC TTG GT & \multirow{3}{*}{85} & \multirow{3}{*}{60} & \multirow{3}{*}{2} \\
\hline & $b l a_{\mathrm{TEM}}-\mathrm{RV}$ & TGC ATA ATT CTC TTA CTG TCA TG & & & \\
\hline & Probe & CCA GTC ACA GAA AAG CAT CTT ACG G & & & \\
\hline \multirow[t]{2}{*}{$\operatorname{erm}(\mathrm{B})$} & $\operatorname{erm}(\mathrm{B})-\mathrm{FW}$ & GGT TGC TCT TGC ACA CTC AAG & \multirow{2}{*}{191} & \multirow{2}{*}{65} & \multirow{2}{*}{3} \\
\hline & $\operatorname{erm}(\mathrm{B})-\mathrm{RV}$ & CAG TTG ACG ATA TTC TCG ATT G & & & \\
\hline \multirow[t]{2}{*}{$\operatorname{erm}(\mathrm{C})$} & $\operatorname{erm}(\mathrm{C})-\mathrm{FW}$ & AAT CGT GGA ATA CGG GTT TGC & \multirow{2}{*}{293} & \multirow{2}{*}{63} & \multirow{2}{*}{3} \\
\hline & $\operatorname{erm}(\mathrm{C})-\mathrm{RV}$ & CGT CAA TTC CTG CAT GTT TTA AGG & & & \\
\hline \multirow[t]{2}{*}{$\operatorname{erm}(\mathrm{F})$} & $\operatorname{erm}(\mathrm{F})-\mathrm{FW}$ & TCT GGG AGG TTC CAT TGT CC & \multirow{2}{*}{412} & \multirow{2}{*}{65} & \multirow{2}{*}{3} \\
\hline & $\operatorname{erm}(\mathrm{F})-\mathrm{RV}$ & TTC AGG GAC AAC TTC CAG C & & & \\
\hline \multirow[t]{2}{*}{ intI1 } & qINT-3 & TGC CGT GAT CGA AAT CCA GAT CCT & \multirow{2}{*}{109} & \multirow{2}{*}{60} & \multirow{2}{*}{4} \\
\hline & qINT-4 & TTT CTG GAA GGC GAG CAT CGT TTG & & & \\
\hline \multirow[t]{2}{*}{$\operatorname{tet}(\mathrm{D})$} & $\operatorname{tet}(\mathrm{D})-\mathrm{FW}$ & GAA TGC CTG CAC CTT TCT GAT G & \multirow{2}{*}{346} & \multirow{2}{*}{62} & \multirow{2}{*}{5} \\
\hline & tet(D)-RV & GGC AAT AAA TCC GGC GAA AA & & & \\
\hline \multirow[t]{2}{*}{$\operatorname{tet}(\mathrm{O})$} & $\operatorname{tet}(\mathrm{O})-\mathrm{FW}$ & ACG GAR AGT TTA TTG TAT ACC & \multirow{2}{*}{171} & \multirow{2}{*}{50.3} & \multirow{2}{*}{$6,7 *$} \\
\hline & $\operatorname{tet}(\mathrm{O})-\mathrm{RV}$ & TGG CGT ATC TAT AAT GTT GAC & & & \\
\hline \multirow[t]{2}{*}{$\operatorname{tet}(\mathrm{Q})$} & $\operatorname{tet}(\mathrm{Q})-\mathrm{FW}$ & AGA ATC TGC TGT TTG CCA GTG & \multirow{2}{*}{167} & \multirow{2}{*}{63} & 6 \\
\hline & $\operatorname{tet}(\mathrm{Q})-\mathrm{RV}$ & CGG AGT GTC AAT GAT ATT GCA & & & \\
\hline $\operatorname{tet}(\mathrm{X})$ & $\operatorname{tet}(\mathrm{X})-\mathrm{FW}$ & AGC CTT ACC AAT GGG TGT AAA & & & 8 \\
\hline & $\operatorname{tet}(\mathrm{X})-\mathrm{RV}$ & TTC TTA CCT TGG ACA TCC CG & & & \\
\hline
\end{tabular}

82 *Primer sequence from Aminov et al. 2009 and annealing temperature from Pei et al. 2006. 83 
84 Table S2. Primers used in endpoint PCR assays (if different from qPCR primers)

\begin{tabular}{|c|c|c|c|c|c|}
\hline Target gene & Primer & Sequence $\left(5^{\prime}-3^{\prime}\right)$ & $\begin{array}{l}\text { Target } \\
\text { size } \\
\text { (bp) }\end{array}$ & $\begin{array}{c}\text { Annealing } \\
\text { temperature } \\
\left({ }^{\circ} \mathrm{C}\right)\end{array}$ & Reference \\
\hline \multirow[t]{2}{*}{ 16S rRNA gene } & $27 \mathrm{~F}$ & AGA GTT TGA TCM TGG CTC AG & \multirow{2}{*}{1,484} & \multirow{2}{*}{55} & \multirow{2}{*}{9} \\
\hline & $1492 \mathrm{R}$ & GGW TAC CTT GTT ACG ACT T & & & \\
\hline \multirow[t]{2}{*}{$\operatorname{tet}(\mathrm{D})$} & $\operatorname{tet}(\mathrm{D})-\mathrm{FW}$ & AAA CCA TTA CGG CAT TCT GC & \multirow{2}{*}{787} & \multirow{2}{*}{55} & \multirow{2}{*}{10} \\
\hline & $\operatorname{tet}(\mathrm{D})-\mathrm{RV}$ & GAC CGG ATA CAC CAT CCA TC & & & \\
\hline \multirow[t]{2}{*}{$\operatorname{tet}(\mathrm{O})$} & $\operatorname{tet}(\mathrm{O})-\mathrm{FW}$ & AAC TTA GGC ATT CTG GCT CAC & \multirow{2}{*}{515} & \multirow{2}{*}{55} & \multirow{2}{*}{10} \\
\hline & tet $(\mathrm{O})-\mathrm{RV}$ & TCC CAC TGT TCC ATA TCG TCA & & & \\
\hline
\end{tabular}


87 Table S3. qPCR assay reaction conditions, linear ranges, and efficiencies

\begin{tabular}{cccc} 
Target gene & $\begin{array}{c}\text { Linear range } \\
(\text { gene copies/ } \mu \mathrm{L})\end{array}$ & $\mathrm{R}^{2}$ & Efficiency \\
\hline $16 \mathrm{~s}$ rRNA & $10^{2}-10^{8}$ & $\geq 0.998$ & $88 \%-94 \%$ \\
$\operatorname{bla}_{\mathrm{TEM}}$ & $10^{1}-10^{8}$ & $\geq 0.990$ & $82 \%-90 \%$ \\
$\operatorname{erm}(\mathrm{B})$ & $10^{1}-10^{8}$ & $\geq 0.995$ & $85 \%-95 \%$ \\
$\operatorname{erm}(\mathrm{C})$ & $10^{2}-10^{8}$ & $\geq 0.999$ & $86 \%-91 \%$ \\
$\operatorname{erm}(\mathrm{F})$ & $10^{1}-10^{8}$ & $\geq 0.993$ & $84 \%-103 \%$ \\
$\operatorname{int} \mathrm{I} 1$ & $10^{1}-10^{8}$ & $\geq 0.995$ & $84 \%-92 \%$ \\
$\operatorname{tet}(\mathrm{D})$ & $10^{1}-10^{8}$ & $\geq 0.998$ & $80 \%-84 \%$ \\
$\operatorname{tet}(\mathrm{O})$ & $10^{1}-10^{8}$ & $\geq 0.994$ & $97 \%-105 \%$ \\
$\operatorname{tet}(\mathrm{Q})$ & $10^{1}-10^{8}$ & $\geq 0.997$ & $88 \%-101 \%$ \\
$\operatorname{tet}(\mathrm{X})$ & $10^{2}-10^{8}$ & $\geq 0.997$ & $78 \%-88 \%$ \\
\hline
\end{tabular}

88 
89 Table S4. Multiple reaction monitoring (MRM) transitions used and source conditions for

90 analytes, internal standards $(*)$ and surrogate $(* *)$ compounds.

91

92

\begin{tabular}{llllll}
\hline Compound & $\begin{array}{l}\text { Parent Ion } \\
(\mathrm{m} / \mathrm{z})\end{array}$ & $\begin{array}{l}\text { Product } \\
\text { Ion }(\mathrm{m} / \mathrm{z})\end{array}$ & $\begin{array}{l}\text { Fragmentor } \\
\text { Voltage }(\mathrm{V})\end{array}$ & $\begin{array}{l}\text { Collision } \\
\text { Energy }(\mathrm{eV})\end{array}$ & $\begin{array}{l}\text { Retention } \\
\text { time }(\mathrm{min}) \\
(\end{array}$ \\
\hline Chlortetracycline & 479 & 462 & 110 & 16 & 12.92 \\
Doxycycline* & 445 & 428 & 120 & 15 & 13.02 \\
Lincomycin & 407 & 126 & 90 & 30 & 12.04 \\
Neotame & 379 & 172 & 150 & 20 & 14.63 \\
Oleandomycin** & 688.85 & 158.2 & 130 & 25 & 13.07 \\
Penicillin G & 335 & 160 & 70 & 5 & 13.21 \\
Penicillin V* & 351 & 160 & 70 & 5 & 13.58 \\
Penillic acid & 335 & 176 & 70 & 10 & 13.18 \\
Roxithromycin* & 837.5 & 158 & 170 & 35 & 14.48 \\
Tiamulin & 494.7 & 191.9 & 70 & 15 & 13.68 \\
\hline
\end{tabular}


93 Table S5. Impact of manure application on the ARG (copy $/ \mathrm{mL})$ and antibiotic $(\mu \mathrm{g} / \mathrm{L})$ concentrations in runoff from plots with the $18.3 \mathrm{~m}$ setback 94 distance.

\begin{tabular}{|c|c|c|c|c|c|c|c|c|c|c|c|c|c|}
\hline & $\begin{array}{c}16 \mathrm{~S} \\
\text { rRNA }\end{array}$ & bla $_{\mathrm{TEM}}$ & $\operatorname{erm}(\mathrm{B})$ & $\operatorname{erm}(\mathrm{C})$ & $\operatorname{erm}(\mathbf{F})$ & intII & $\operatorname{tet}(\mathrm{D})$ & $\operatorname{tet}(\mathrm{O})$ & $\operatorname{tet}(\mathrm{Q})$ & $\operatorname{tet}(\mathrm{X})$ & $\mathrm{CTC}^{\mathrm{c}}$ & $\mathbf{L I N}^{\mathbf{d}}$ & $\mathbf{T I A}^{\mathrm{e}}$ \\
\hline \multicolumn{14}{|c|}{ Manure Application } \\
\hline $\begin{array}{l}\text { Amended plots } \\
\text { (with manure) }\end{array}$ & $4.0 \times 10^{5}$ & $2.8 \times 10^{3}$ & $7.6 \times 10^{4} \mathrm{a}$ & $3.7 \times 10^{3}$ & $5.2 \times 10^{4} \mathrm{a}$ & $2.8 \times 10^{4} \mathrm{a}$ & $2.0 \times 10^{1}$ & $4.5 \times 10^{2}$ & $3.5 \times 10^{3} \mathrm{a}$ & $3.9 \times 10^{4}$ & 1.48 & $1.11 \mathrm{a}$ & 0.015 \\
\hline $\begin{array}{l}\text { Control plots } \\
\text { (without manure) }\end{array}$ & $9.5 \times 10^{3}$ & $4.4 \times 10^{2}$ & $6.9 \times 10^{1} \mathrm{~b}$ & $\mathrm{BDL}^{\mathrm{a}}$ & $4.0 \times 10^{2} \mathrm{~b}$ & $7.4 \times 10^{1} \mathrm{~b}$ & $3.0 \times 10^{1}$ & BDL & $9.6 \times 10^{1} \mathrm{~b}$ & $1.3 \times 10^{3}$ & BDL & $0.01 \mathrm{~b}$ & $\mathrm{BDL}$ \\
\hline p-values: & 0.113 & 0.172 & 0.004 & $\mathrm{~N} / \mathrm{A}^{\mathrm{b}}$ & 0.029 & 0.004 & 0.526 & N/A & 0.009 & 0.561 & N/A & $<0.001$ & $\mathrm{~N} / \mathrm{A}$ \\
\hline
\end{tabular}

95 aBDL, below detection limit, indicates that there were too few values above detection limit to estimate an average

96 bN/A, not applicable, indicates that there were too few values to successfully run ANOVA.

$97 \quad$ CTC; chlortetracycline

98 dLIN; lincomycin

99 eTIA; tiamulin

100

101 
Table S6. Impact of manure application on the ARG (copy/g dw) and antibiotic (ng/g dw) concentrations in soil.

\begin{tabular}{|c|c|c|c|c|c|c|c|c|c|c|c|c|c|}
\hline & $\begin{array}{c}16 \mathrm{~S} \\
\text { rRNA }\end{array}$ & $b l a_{\mathrm{TEM}}$ & $\operatorname{erm}(\mathrm{B})$ & $\operatorname{erm}(\mathrm{C})$ & $\operatorname{erm}(\mathbf{F})$ & intI1 & $\operatorname{tet}(\mathrm{D})$ & $\operatorname{tet}(\mathbf{0})$ & $\operatorname{tet}(\mathrm{Q})$ & $\operatorname{tet}(\mathrm{X})$ & $\mathrm{CTC}^{\mathrm{c}}$ & $\mathbf{L I N}^{\mathbf{d}}$ & TIA $^{\mathrm{e}}$ \\
\hline \multicolumn{14}{|c|}{ Manure Application } \\
\hline $\begin{array}{l}\text { Amended plot } \\
\text { (with manure) }\end{array}$ & $5.8 \times 10^{7}$ & $2.4 \times 10^{4}$ & $1.6 \times 10^{6}$ & $1.3 \times 10^{6}$ & $7.4 \times 10^{5}$ & $2.9 \times 10^{6}$ & $1.8 \times 10^{4}$ & $3.5 \times 10^{4}$ & $7.7 \times 10^{5}$ & $1.2 \times 10^{6}$ & 51.2 & 0.75 & 6.35 \\
\hline $\begin{array}{l}\text { Control plot } \\
\text { (without manure) }\end{array}$ & $1.1 \times 10^{8}$ & $2.0 \times 10^{4}$ & $\mathrm{BDL}^{\mathrm{a}}$ & BDL & BDL & $1.5 \times 10^{4}$ & $1.6 \times 10^{4}$ & BDL & BDL & $\mathrm{BDL}$ & 0.62 & BDL & $\mathrm{BDL}$ \\
\hline p-values: & 0.443 & 0.558 & $\mathrm{~N} / \mathrm{A}^{\mathrm{b}}$ & N/A & N/A & 0.003 & 0.466 & $\mathrm{~N} / \mathrm{A}$ & N/A & $\mathrm{N} / \mathrm{A}$ & 0.017 & $\mathrm{~N} / \mathrm{A}$ & N/A \\
\hline
\end{tabular}

103 aDL, below detection limit, indicates that there were too few values above detection limit to estimate an average.

104 bN/A, not applicable, indicates that there were too few values for ANOVA to return a $p$-value.

105 'CTC; chlortetracycline

106 dLIN; lincomycin

107 eTIA; tiamulin 


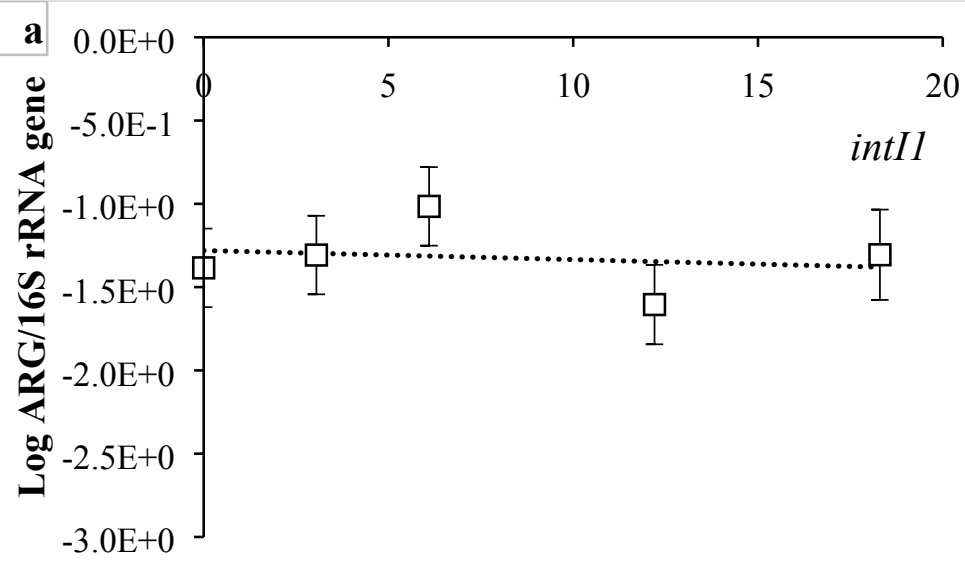

108

Setback distance (m)

109

110

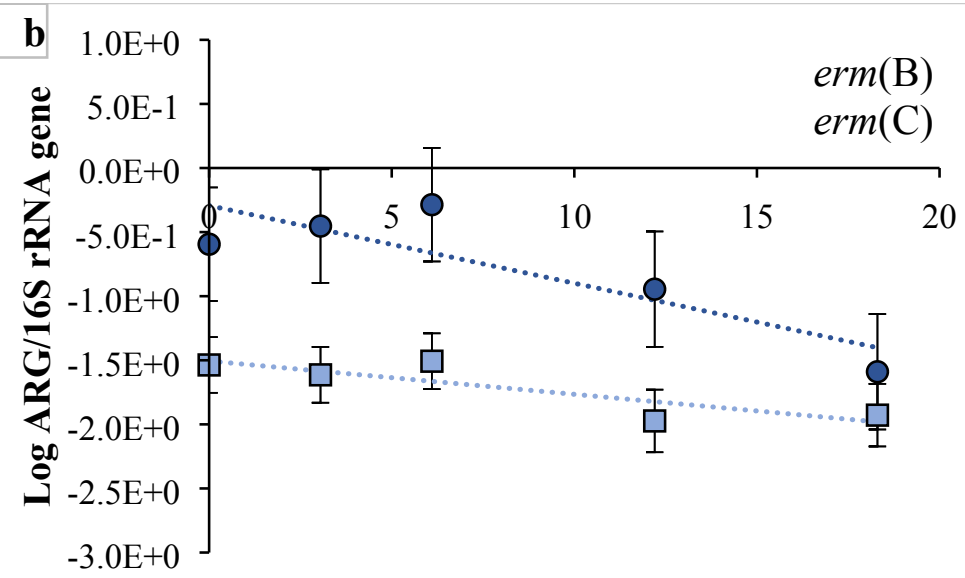

Setback distance (m)

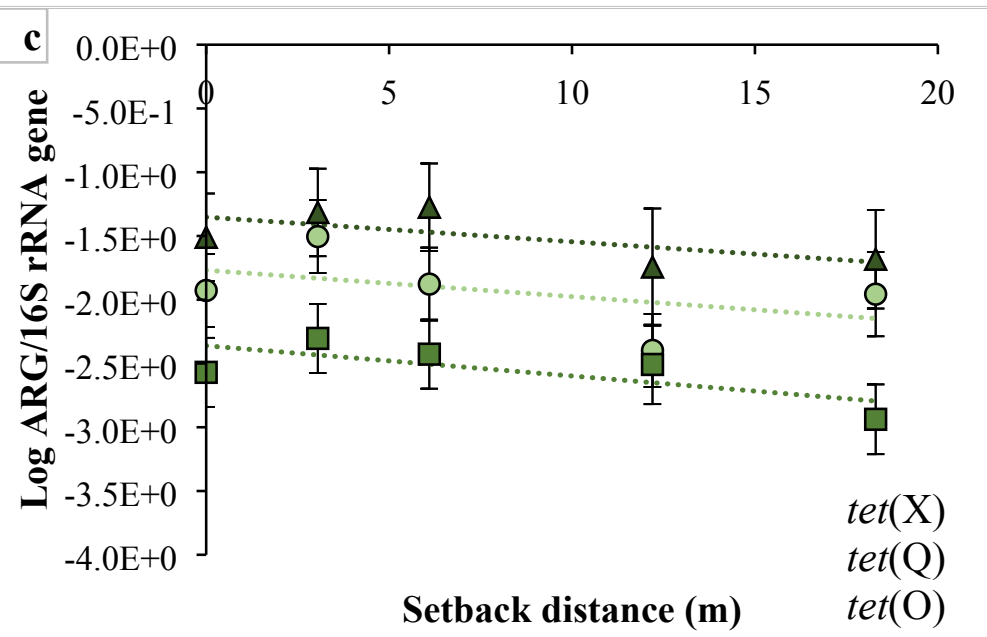

111

112

Figure S1. Means of log concentration of the relative abundance of (a) intI1, (b) erythromycin

113 resistance methylase $(\mathrm{erm})$ genes, and (c) tetracycline resistance (tet) genes in runoff from

114 manure-amended plots after the rainfall \#1. The error bars represent the standard errors based on 115 the ANOVA analysis with GLIMMIX. The trendlines are linear. 

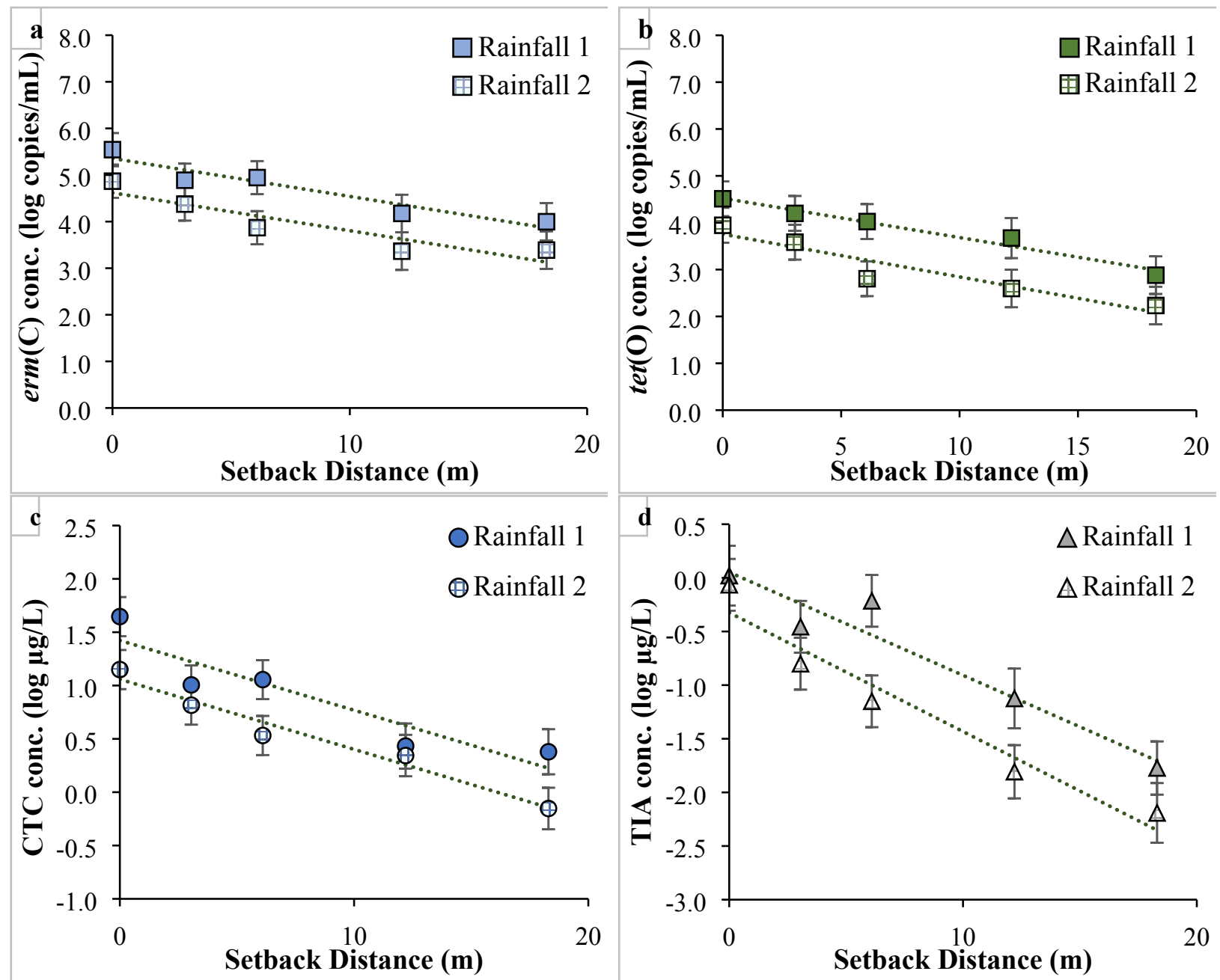

117 Figure S2. Weighted average concentration of (a) $\operatorname{erm}(\mathrm{C})$, (b) tet(O), (c) chlortetracycline (CTC), 118 and (d) tiamulin (TIA) in runoff during rainfall \#1 and rainfall \#2. The error bars represent the 119 standard errors based on the ANOVA analysis of replicates and distance using GLIMMIX. 


\section{References}

1. Suzuki, M. T.; Taylor, L. T.; DeLong, E. F.,Quantitative analysis of small-subunit rRNA genes in mixed microbial populations via 5 '-nuclease assays. Appl. Environ. Microbiol. 2000, 66, (11), 4605-4614.

2. Lachmayr, K. L.; Kerkhof, L. J.; DiRienzo, A. G.; Cavanaugh, C. M.; Ford, T. E.,Quantifying Nonspecific TEM beta-Lactamase (bla(TEM)) Genes in a Wastewater Stream. Appl. Environ. Microbiol. 2009, 75, (1), 203-211.

3. Koike, S.; Aminov, R. I.; Yannarell, A. C.; Gans, H. D.; Krapac, I. G.; Chee-Sanford, J. C.; Mackie, R. I.,Molecular ecology of Macrolide-Lincosamide-Streptogramin B methylases in waste lagoons and subsurface waters associated with swine production. Microb. Ecol. 2010, 59, (3), 487-498.

4. Rosewarne, C. P.; Pettigrove, V.; Stokes, H. W.; Parsons, Y. M.,Class 1 integrons in benthic bacterial communities: abundance, association with Tn402-like transposition modules and evidence for coselection with heavy-metal resistance. FEMS Microbiol Ecol 2010, 72, (1), $35-46$.

5. Fan, W.; Hamilton, T.; Webster-Sesay, S.; Nikolich, M. P.; Lindler, L. E.,Multiplex real-time SYBR Green IPCR assay for detection of tetracycline efflux genes of Gram-negative bacteria. Mol. Cell. Probes 2007, 21, (4), 245-256.

6. Aminov, R. I.; Garrigues-Jeanjean, N.; Mackie, R. I.,Molecular ecology of tetracycline resistance: Development and validation of primers for detection of tetracycline resistance genes encoding ribosomal protection proteins. Appl. Environ. Microbiol. 2001, 67, (1), 2232.

7. Pei, R. T.; Kim, S. C.; Carlson, K. H.; Pruden, A.,Effect of River Landscape on the sediment concentrations of antibiotics and corresponding antibiotic resistance genes (ARG). Water Res. 2006, 40, (12), 2427-2435.

8. Ghosh, S.; Ramsden, S. J.; LaPara, T. M.,The role of anaerobic digestion in controlling the release of tetracycline resistance genes and class 1 integrons from municipal wastewater treatment plants. Appl. Microbiol. Biotechnol. 2009, 84, (4), 791-796.

9. Suzuki, M. T.; Giovannoni, S. J.,Bias caused by template annealing in the amplification of mixtures of 16S rRNA genes by PCR. Appl. Environ. Microbiol. 1996, 62, (2), 625-630.

10. Ng, L. K.; Martin, I.; Alfa, M.; Mulvey, M.,Multiplex PCR for the detection of tetracycline resistant genes. Mol. Cell. Probes 2001, 15, (4), 209-215. 